\title{
On the role of macrophages in the control of adipocyte energy metabolism
}

\author{
Michaela Keuper \\ Department of Molecular Biosciences, The Wenner-Gren Institute, Stockholm University, Stockholm, Sweden
}

Correspondence should be addressed to M Keuper: michaela.keuper@su.se

\begin{abstract}
The crosstalk between macrophages $(M \Phi)$ and adipocytes within white adipose tissue (WAT) influences obesity-associated insulin resistance and other associated metabolic disorders, such as atherosclerosis, hypertension and type 2 diabetes. MФ infiltration is increased in WAT during obesity, which is linked to decreased mitochondrial content and activity. The mechanistic interplay between $\mathrm{M} \Phi$ and mitochondrial function of adipocytes is under intense investigation, as $M \Phi$ and inflammatory pathways exhibit a pivotal role in the reprogramming of WAT metabolism in physiological responses during cold, fasting and exercise. Thus, the underlying immunometabolic pathways may offer therapeutic targets to correct obesity and metabolic disease. Here, I review the current knowledge on the quantity and the quality of human adipose tissue macrophages (ATM $\Phi)$ and their impact on the bioenergetics of human adipocytes. The effects of ATMФ and their secreted factors on mitochondrial function of white adipocytes are discussed, including recent research on MФ as part of an immune signaling cascade involved in the 'browning' of WAT, which is defined as the conversion from white, energy-storing adipocytes into brown, energydissipating adipocytes.
\end{abstract}

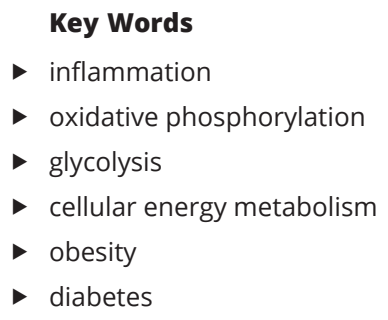

\section{Introduction}

White adipose tissue (WAT) is a metabolically active tissue that modifies systemic metabolism significantly by regulating the storage and release of lipids. Free fatty acids serve as a major fuel source during times of energy scarcity and high energy demands, such as exercise, cold exposure and immune responses. The dysregulation of fatty acid release contributes to dyslipidemia, resulting in ectopic fat deposition into various organs. Ectopic fat in turn impairs organ functionality, as seen during many metabolic diseases. Importantly, WAT also releases metabolites other than fatty acids (e.g. lactate as glycolytic end-product) (1). Beyond the direct metabolic effects, WAT also mediates endocrine crosstalk by secretion of various adipokines (e.g. adiponectin and leptin) $(2,3)$.

The crucial role of mitochondrial activity for WAT function is well established and impacts the capacity of lipid storage $(4,5)$ and secretory function $(6,7,8)$.
Clinical studies substantiate the strong association between decreased mitochondrial content and oxygen consumption of WAT/adipocytes, which is in particular evident during metabolic complications such as insulin resistance, type 2 diabetes (T2DM) and cardiovascular diseases $(9,10,11,12,13)$. A crucial hallmark in the development of obesity-associated metabolic disorders is the chronic, low-grade inflammation of WAT (14, 15). Although obesity-associated inflammation and macrophage $(\mathrm{M} \Phi)$ infiltration affect many tissues (such as liver, muscle, brain and pancreas $(16,17,18,19,20)$ ), the infiltration into WAT is disproportionately increased. Notably, it has been suggested that the obesity-associated inflammation of human WAT compromises mitochondrial function $(21,22,23,24)$.

Adipose tissue macrophages (ATM $\Phi$ ) also reside in the WAT of lean and healthy individuals, suggesting a 
fundamental physiological role for $\mathrm{ATM} \Phi$, beyond the context of pathology (Fig. 1). Some inflammatory processes appear to be important for healthy WAT expansion (25). The ATM $\Phi$-secreted cytokines and chemokines act in an autocrine and paracrine manner, the latter by controlling the inflammatory response of other immune cells or possibly impacting the metabolism of adjacent adipocytes. Recent mouse studies suggest the secretion of АTM $\Phi$ factors that metabolically enhance adipocytes during cold, stress and exercise $(26,27,28)$, which has been broadly termed the 'browning' of WAT. Some mechanistic aspects of $\mathrm{M} \Phi$-induced browning have been questioned $(29,30)$, but most studies collectively support a role for $\mathrm{M} \Phi$ in the energy metabolism of adipocytes, in particular controlling adipocyte mitochondrial function $(26,27,31,32,33,34)$.

Taken together, there is accumulating evidence that ATM $\Phi$ enhances or suppresses the mitochondrial function in WAT. The understanding of how adipocyte energy metabolism and mitochondria are regulated during physiological and pathophysiological adaptation requires the mechanistic understanding of the immunometabolic interaction between ATM $\Phi$ and adipocytes. The molecular networks of this interaction may offer potential interference points to correct imbalanced metabolism during pathological situations such as obesity and T2DM.

\section{Adipose tissue macrophages (ATM $\Phi)$}

\section{MФ number increases in human white adipose tissue} during obesity

ATM $\Phi$ are numerically the dominant type of immune cells in human WAT, and obesity further enhances $\mathrm{M} \Phi$ numbers in WAT, which contributes to obesity-related immune imbalances (Fig. 1A). However, the data on the
A

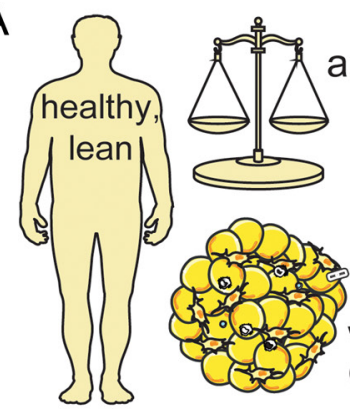

anti-inflammatory pro-inflammatory

B

white adipose tissue

Obesity-associated impaired immune balance

(WAT)

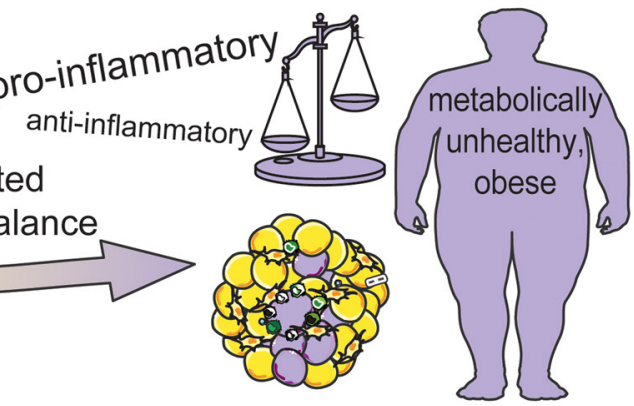

B subcutaneous WAT<smiles>c1ccc2c(c1)CCCCCCCC2</smiles>

$50-70 \%$ adipocytes fraction (SVF)

C help to maintain tissue homeostasis low number interspersed between adipocytes lower inflammatory molecular signature contribute to tissue dysfunction high number

local accumulation ('crown-like structures') higher inflammatory molecular signature

\section{Figure 1}

Obesity-associated impaired immune balance in white adipose tissue. (A) Obesity is associated with an impaired immune balance toward proinflammatory in WAT. All fat depots are affected, but mostly the viscWAT. (B) ATMФ amount is low in lean scWAT ( 13\% of SVF). However, MФ are numerically the dominant type of immune cells representing half of the immune cells. MФ increase in obese WAT, for example in human scWAT from 13 to $20 \%$ of the SVF (36). (C) The roles of ATMФ in lean (left) and obese (right) WAT. The number of M $\Phi$ is low and they are interspersed between adipocytes in WAT of lean subjects, contrasting the higher number and local accumulation of MФ in crown-like structures during obesity, which is fostered by proliferation, high immigration and low emigration. The low inflammatory profile (surface markers, cytokine expression and secretion, e.g. IL4, IL10) in lean subjects transforms into higher inflammatory status (e.g. TNFa, IL6, IL1ß) during obesity.

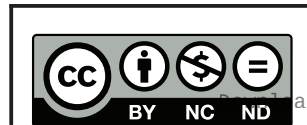

This work is licensed under a Creative Commons Attribution-NonCommercial-NoDerivatives 4.0 Internationab bicense.ifica . com at $04 / 26 / 2023$ 08:03:11AM 
cellular composition of WAT (and thus the amount of ATM $\Phi$ ) vary quantitatively between studies, depending on donor, fat depot, WAT isolation/processing method and molecular readout. The relative amount of $\mathrm{M} \Phi$ varies from as little as $\leq 1 \%$ (CD11 $\mathrm{c}^{+}$cells, immunohistochemistry) in lean human scWAT (35), to up to $40 \%$ in obese scWAT, as seen in the first report from Weisberg et al. $\left(\mathrm{CD}^{+} 8^{+}\right.$cells, immunohistochemistry) (24). The recent publication from Ehrlund et al. found that the stromal vascular fraction (SVF) of scWAT from lean donors consists of $\sim 60 \%$ progenitors including preadipocytes, $\sim 3 \%$ endothelial cells, $\sim 25 \%$ immune cells (and an undetermined rest) (36) (Fig. 1B). Half of this immune cell population is represented by $\mathrm{M} \Phi\left(\mathrm{CD} 45^{+} / \mathrm{CD} 14^{+}\right.$cells), whereas the other half is represented by T cells, B cells, mast cells, neutrophils and eosinophils. This study also reports that $\mathrm{M} \Phi$ content significantly increases during obesity to $20 \%$ of SVF in scWAT (36). The identified numbers of 13\% M $\Phi$ in lean scWAT and $20 \%$ in obese scWAT (Fig. 1B) agree well with other reports $(35,37,38,39,40,41,42,43,44$, $45,46)$. Several publications show increased $\mathrm{M} \Phi$ numbers in WAT during obesity that are more pronounced in viscWAT than in scWAT $(47,48,49)$. The ATM $\Phi$ numbers in both viscWAT and scWAT correlate with BMI $(24,40$, 50). Although АTM $\Phi$ increase significantly in viscWAT during obesity, a recent publication also notes that the relative contribution of M $\Phi$ to the SVF is much smaller in viscWAT (lean: 3\%; obese: 7\%) as compared to scWAT (51). Comparing immune cell populations in viscWAT from lean, middle-aged, male mice to cynomolgus macaques and healthy humans revealed that $\mathrm{M} \Phi$ are the dominant immune cell type in murine viscWAT, whereas in humans and cynomolgus macaques, $\mathrm{T}$ cells dominate, followed by $\mathrm{M} \Phi$ as the second largest immune cell population (52). Considering these cross-species comparisons, $\mathrm{M} \Phi$ may not always be the most abundant immune cell type in adipose tissue. Nevertheless, $\mathrm{M} \Phi$ are present in scWAT and viscWAT with increasing numbers during obesity. Furthermore, the obese condition alters their quality, comprising the mode of activation and the diversity of the secretome.

\section{The local accumulation of ATMФ in obese WAT}

Excessive energy intake (overnutrition) is broadly accepted as an inducer of increased ATM $\Phi$ infiltration in obese WAT, causing adipocyte hypertrophy and hypoxia, eventually leading to adipocyte dysfunction, cell death and fibrosis. This scenario is accompanied by higher levels of chemoattractant cytokines such as chemokine
(C-C motif) ligand 2 (CCL2/MCP-1), chemokine (C-C motif) ligand 3 (CCL3/MIP1a) and others. These cytokines provide a chemotactic gradient that attracts monocytes into WAT $(39,53,54,55)$. Inside WAT, monocytes enhance the chemotactic gradient by secreting their own chemokines, thereby attracting additional $\mathrm{M} \Phi$ and setting up a feed-forward inflammatory process. Between lean and obese, not only the number of $\mathrm{M} \Phi$ changes, but also their localization: In lean WAT, ATM $\Phi$ are interstitially spaced, contrasting the local accumulation of ATM $\Phi$ in so-called 'crown-like structures' around dead, apoptotic adipocytes and/or fibrotic areas in obese WAT $(35,50,56)$. Mouse studies indicate that the increased M $\Phi$ content in obese WAT presumably results from several processes: higher rates of recruited/infiltrating monocytes (e.g. via CCL2, see above) $(57,58,59)$, proliferation of WATresident monocytes $(60,61)$ and lower emigration rates of ATM $\Phi$ out of obese WAT (e.g. via netrin 1) (62).

\section{The physiological importance of dynamic ATMФ for WAT biology}

ATM $\Phi$ exert distinct physiological roles and beneficial effects on WAT homeostasis, for example, healthy lipid storage $(25,26,63,64,65)$ (Fig. 1C). АTM $\Phi$ are dynamic cells and they quickly adapt their phenotype and metabolism to changing environments, for example during fastinginduced WAT lipolysis $(65,66)$ and overnutrition (67). $\operatorname{ATM} \Phi$ stimulate healthy lipid storage and therefore prevent adverse ectopic lipid storage in other organs (e.g. hepatic steatosis). Anti- and pro-inflammatory signals seem to be involved in maintaining WAT homeostasis: Healthy WAT expansion is impaired by ablating tissueresident ATM $\Phi$ (anti-inflammatory M2) (68) or reducing pro-inflammatory signals in murine WAT (25). Recently, ATM $\Phi$ function has been implicated in cold adaptation and exercise of mice $(27,28)$. IL4-activated M $\Phi$ appear to be part of an anti-inflammatory signaling cascade contributing to cold-induced browning and recruitment of beige adipocytes in scWAT $(26,27,28,63,69,70)$. The underlying molecular mechanisms, however, and some of the reported effects have been controversially discussed $(29,30)$. The potential role of АTM $\Phi$ in browning will be detailed in later sections.

\section{АТМФ display a mixed phenotype in obese WAT}

One of the first studies investigating ATM $\Phi$ proposed a phenotypic switch during obesity: while resident M2-like $\operatorname{ATM} \Phi$ dominate in lean WAT, pro-inflammatory (M1)

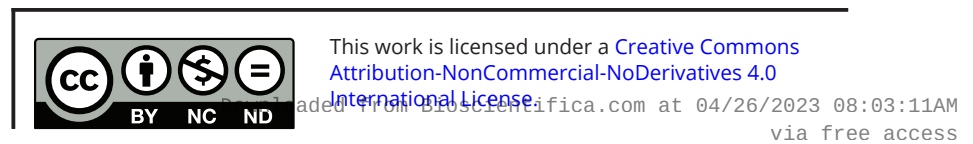


ATM $\Phi$ dominate in obese WAT (71). The stressed, obese WAT is marked by elevated levels of fatty acids and LPS, which can activate TLR4 signaling to polarize M $\Phi$ toward the pro-inflammatory M1 phenotype (72). Thus, ATM $\Phi$ can resemble the phenotype of LPS and IFN $\gamma$-activated M $\Phi$ during diet-induced obesity $(15,24,37)$. This simplified classification of anti- (M2) vs pro- (M1) inflammatory activated $M \Phi$, however, does not reflect the actual situation in vivo, where a spectrum of mixed markers is found (73). Notably, there are also species differences on the molecular level between human and murine ATM $\Phi$. For example, the markers commonly used for murine $\mathrm{M} \Phi$ polarization, such as inducible nitric oxide synthase (iNos) and arginase 1 (Arg1), are barely expressed in human ATM $\Phi(74,75,76,77)$. Recently, several different ATM $\Phi$ subtypes have been identified in obese human WAT expressing macrophage activation markers of both the M1 spectrum (e.g. CD11c) and the M2 spectrum (e.g. CD163, CD206) (51, 78, 79, 80, 81). Additionally, human ATM $\Phi$ displaying M2 surface markers are capable of secreting both, pro- and anti-inflammatory cytokines (82). CD $11 \mathrm{c}^{+}-\mathrm{ATM} \Phi$ show a reduced pro-inflammatory profile after weight loss (79). Thus, in particular during obesity, ATM $\Phi$ cannot be classified using the simple dual M1/M2 model. A new category of MФs, termed 'metabolically' activated $\mathrm{M} \Phi$, was recently proposed, which can be activated by the WAT-specific environment (hormones and nutrients) (83). Indeed, the WAT-specific microenvironment and/or the long retention time of MФ in WAT during obesity may be the cause for the unique phenotype of ATM $\Phi$. Data on monocytes/M $\Phi$ during obesity reveal higher immigration rates into obese WAT (59) and lower emigration rates (62), indicating longer exposure times for ATM $\Phi$ in the WAT microenvironment during obesity.

Dissecting the different spatiotemporal phenotypes of human ATM $\Phi$, including their secreted cytokines, chemokines and other factors, either during acute or chronic metabolic challenges (e.g. feeding/fasting, different diets, exercise, cold), is a challenging task. However, further insights on the role of ATM $\Phi$ in WAT metabolism and dysfunction would be gained from those studies, including the potential to distinguish and classify subgroups of obese patients with high risk for certain obesity-associated metabolic complications (e.g. NAFLD, cardiovascular complications).

In summary, ATM $\Phi$ assist the maintenance of normal tissue function, such as adipokine secretion, healthy lipid storage and adaptation toward metabolic challenges (e.g. cold, exercise, fasting) (Fig. 1C). In obesity, the amount of
ATM $\Phi$ increases through the combination of proliferation, immigration and retention. ATM $\Phi$ accumulate around dead adipocytes in crown-like structures and change their phenotype. Indeed, АTM $\Phi$ of the obese display altered secretion profiles, surface marker expression and metabolic function, thereby contributing to the overall (dys)function of WAT, which will eventually impact whole body metabolic homeostasis.

\section{The bioenergetics of human white fat cells}

\section{Mitochondrial activity is important for lipid storage and secretory function of human white adipocytes}

Synthesis of ATP through oxidative phosphorylation (OXPHOS) is a major function of mitochondria to provide sufficient cellular energy. Therefore, energy-demanding adipose-specific functions, such as endocrine signaling and lipid storage, highly depend on adequate mitochondrial activity. Indirectly, mitochondria also control free fatty acid (FA) levels as the consequence of lipid storage control. Beyond ATP production, mitochondria also generate metabolic intermediates that are required for de novo lipogenesis. For example, the mitochondrial pyruvate dehydrogenase complex (PDH) decarboxylates pyruvate to acetyl-CoA, and thereby regulates glyceroneogenesis and the metabolic switch from glucose to lipid metabolism (4). A similar regulating role of mitochondria is found for the reverse process of lipolysis, the breakdown of lipids. Lipolysis and mitochondrial activity are closely linked as mitochondria facilitate lipolysis through FA oxidation. Furthermore, free FA can uncouple mitochondrial chain activity from ATP synthesis and enhance respiratory activity, while inhibitors of mitochondrial ATP production can abolish catecholamine-stimulated lipolysis $(84,85,86)$.

Mitochondria are also important players in the regulation of $\mathrm{Ca}^{2+}$ homeostasis (87), tying into the welldocumented calcium-dependent processes in adipocytes during insulin-stimulated glucose uptake, leptin secretion and adipogenesis (88, 89, 90, 91, 92). Furthermore, adequate mitochondrial activity is required to execute the endocrine function of WAT (e.g. adiponectin secretion (6)). Finally, the basic processes of adipocyte differentiation and maturation are closely linked to the initiation of de novo mitochondrial biogenesis and reactive oxygen species (ROS) production $(93,94)$. Collectively, mitochondrial activity of adipocytes has an impact on all the essential and specialized functions of WAT, even those that control distantly the processes that maintain systemic homeostasis. 
The bioenergetic profile of (pre-)adipocytes and the regulation by nutrients and hormones

As most proliferating progenitor cells, human subcutaneous preadipocytes depend mainly on glycolytic ATP production ( $85 \%$ from glycolysis vs $15 \%$ from OXPHOS, Fig. 2) (95). During adipogenic differentiation, the mitochondrial content increases several fold (96) and the relative contribution of OXPHOS to total ATP production increases to $45-73 \%$ in human adipocytes $(95,97)$. Comparing mitochondrial oxygen consumption rates (OCRs) revealed four- to five-fold higher OCR in adipocytes as compared with preadipocytes (SGBS and primary cells) $(95,98)$. Of note, at least under in vitro conditions, glycolysis seems to be the preferred energy-producing pathway in both,

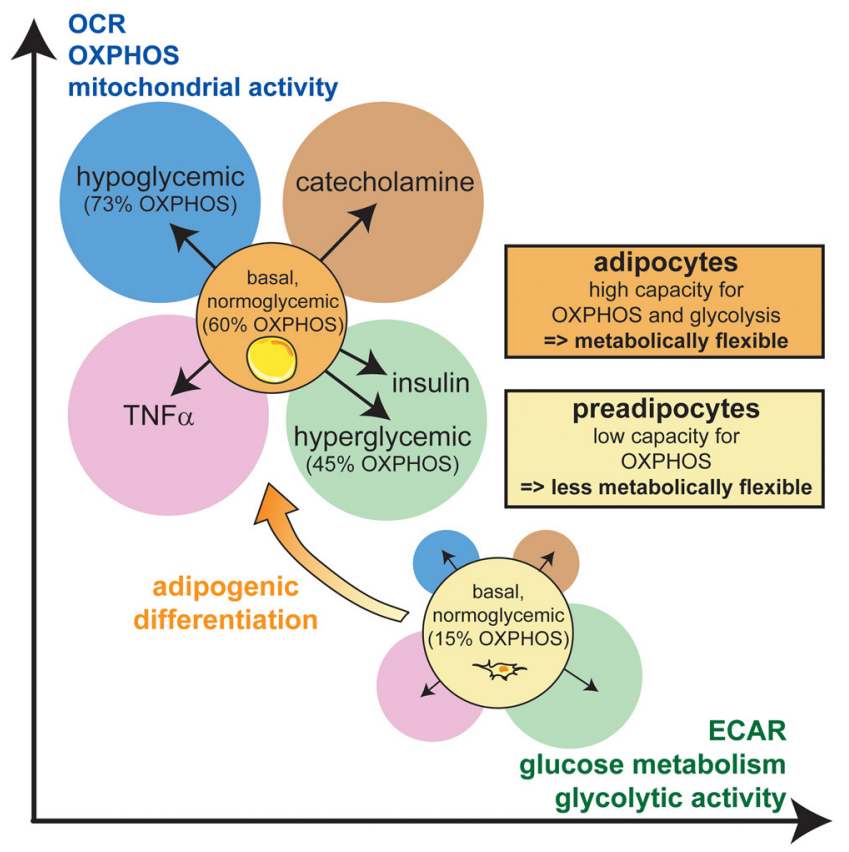

\section{Figure 2}

The dynamics of adipocyte energy metabolism. Oxygen consumption rates (OCRs), representing mitochondrial function, are plotted against extracellular acidification rates (ECARs), representing an estimate for glycolytic activity. Both pathways fuel cellular ATP demands, are complementary and display metabolic flexibility, in particular in healthy, lean adipocytes (orange). Preadipocytes (yellow) display lower OCR, higher ECAR and less metabolic flexibility. During adipogenic differentiation, glycolytic ATP production is replaced by oxidative phosphorylation (OXPHOS). OXPHOS increases about five-fold, and its contribution to cellular ATP increases from $15 \%$ in preadipocytes (yellow circle) to $~ 60 \%$ in adipocytes (orange circle) under basal, normoglycemic conditions. Adipocytes in lean WAT display high flexibility of OCR and ECAR, depending on nutrient availability (e.g. glucose: 45\% OXPHOS in hyperglycemic (green circle) and 73\% OXPHOS in hypoglycemic (blue circle) conditions), depending on hormonal input (e.g. catecholamine (brown circle) induces simultaneous glycolysis and OXPHOS = increased metabolic activity; insulin (green circle) suppresses OXPHOS and increases glycolysis = metabolic shift), and depending on inflammatory mediators (e.g. TNFa (pink circle) is suspected to reduce OCR and ECAR = metabolic depression). preadipocytes and mature adipocytes. Adipocytes partially switch from OXPHOS to glycolysis in the presence of glucose. In the absence of glucose, however, only adipocytes, but not preadipocytes, are able to maintain their ATP demand by increasing mitochondrial activity. Therefore, mitochondria in human adipocytes allow for the high flexibility in substrate choice to maintain their energy metabolism (95). Visceral adipocytes show lower mitochondrial activity than subcutaneous, when calculated per cell and normalized for mitochondrial content $(99,100)$. When comparing isolated mitochondria from subcutaneous and visceral adipocytes, no significant difference in mitochondrial function was observed (9). This indicates that differences in energy metabolism between visceral and subcutaneous adipocytes, and WAT depots, do not depend on intrinsic mitochondrial capacity. Instead, cellular capacity of OXPHOS may depend on mitochondrial mass per cell (e.g. higher mitochondrial density in visceral than subcutaneous adipocytes (99)), the control of mitochondrial function at the cellular level (e.g. higher beta-3 adrenergic receptor mRNA levels in viscWAT than in scWAT (101)) and the depot-specific surrounding (e.g. higher vascularization in viscWAT than scWAT (102)), including the inflammatory environment created by $\mathrm{M} \Phi$ (higher concentration of cytokines such as IL6 in viscWAT than scWAT (103)).

Upon adrenergic activation, subcutaneous adipocytes of lean humans display increased OCR that associates with increased lipolysis (13). In parallel, extracellular acidification rates (ECARs), which estimate glycolytic activity, are increased (13). Notably, the extracellular acidification may also derive from increased carbon dioxide production of the TCA cycle (dissolved as carbonic acid), and therefore, partially unrelated to glycolysis. Insulin stimulation of subcutaneous adipocytes from obese donors leads to increased glycolytic activity and simultaneously, to decreased ATP-linked respiration (104). Whether this response is different in adipocytes from lean donors, or different in visceral adipocytes, needs to be determined. Overall, the high capacity of mitochondrial OXPHOS, that is linked to trigacylglycerol/FA cycling activity and induced by hormones and nutrients, is essential for metabolic flexibility of WAT $(105,106,107)$, representing a marker of healthy adipocytes (Fig. 2).

\section{Obesity-induced changes in the bioenergetics of white adipocytes}

Decreased mitochondrial function in white adipocytes leads to dysfunction in lipid storage and endocrine

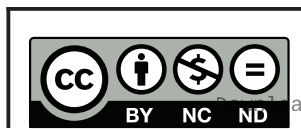

This work is licensed under a Creative Commons Attribution-NonCommercial-NoDerivatives 4.0 Internationab bicense.ifica. com at 04/26/2023 08:03:11AM 
function of WAT $(2,6)$ that associate with obesity-induced metabolic complications such as insulin resistance (108) (Fig. 3). Several studies demonstrate reduced mitochondrial content and activity of subcutaneous and visceral adipocytes from obese donors $(9,10,12,13$, $109)$ independent of fat cell size $(9,12)$. Furthermore, subcutaneous adipocytes from obese donors show lower OCR responses after $\beta$-adrenergic stimulation as compared to lean individuals (13). The depression of ATP metabolism in adipocytes from obese donors is supported by data on lower mitochondrial activity, reduced lipid accumulation and insulin-stimulated glucose uptake, as compared to SGBS adipocytes, which represent a model for lean, insulin-sensitive human white subcutaneous adipocytes (110). In line with these observations, previous studies on basal heat production of primary ('floating') adipocytes from lean vs obese humans revealed an obesity-related reduction in heat output by $\sim 50 \%$ (111). Interestingly, not only impaired mitochondrial function but also altered glycolytic activity in adipocytes is associated with obesity. Higher lactate secretion of WAT from obese patients has been reported previously, indicating higher glycolytic fluxes, impaired conversion of lactate to pyruvate and/or impaired pyruvate import into the mitochondria $(1,112$, 113). This is in line with suggestions on the increased requirement of glycolytic energy production during insulin resistance (114). Under hypoxic condition, adipocytes show increased glucose uptake, leading to glycogen accumulation that has been linked to impaired adipokine secretion (115). Additionally, mitochondrial uncoupling in adipocytes, either induced by overexpressing uncoupling protein 1 (UCP1) or by administration of chemical uncouplers such as FCCP, results in less ATP yield from OXPHOS. This is usually compensated by the increase of glycolytic energy production. If the compensation fails to maintain ATP homeostasis, adipocytes show reduced lipid accumulation, possibly by diverting glucose-derived carbon flux away from fatty acid synthesis into lactate production $(116,117,118,119)$. This reduction in lipid accumulation capacity of adipocytes may lead to the adverse lipid accumulation in other organs (e.g. NAFLD), a commonly seen feature in metabolically unhealthy obese patients (120). Thus, appropriate functionality, balance and regulation of the main energy-producing pathways, oxidative phosphorylation and glycolysis, is important for metabolic flexibility to retain healthy adipocytes. Any perturbation of these metabolic processes leads to metabolic imbalances and adverse outcomes for the whole metabolic system of the body.

In summary (Fig. 3), healthy adipocytes possess the adequate mitochondrial mass and activity, allowing a wide scope of metabolic responses to hormones such as insulin and adrenaline. Mitochondrial function is required for insulin-stimulated glucose metabolism and adrenergic-stimulated OXPHOS capacity, allowing for rapid adjustments of energy metabolism. Obesity is characterized by lower mitochondria number and activity, altered basal/insulin-stimulated glucose metabolism and
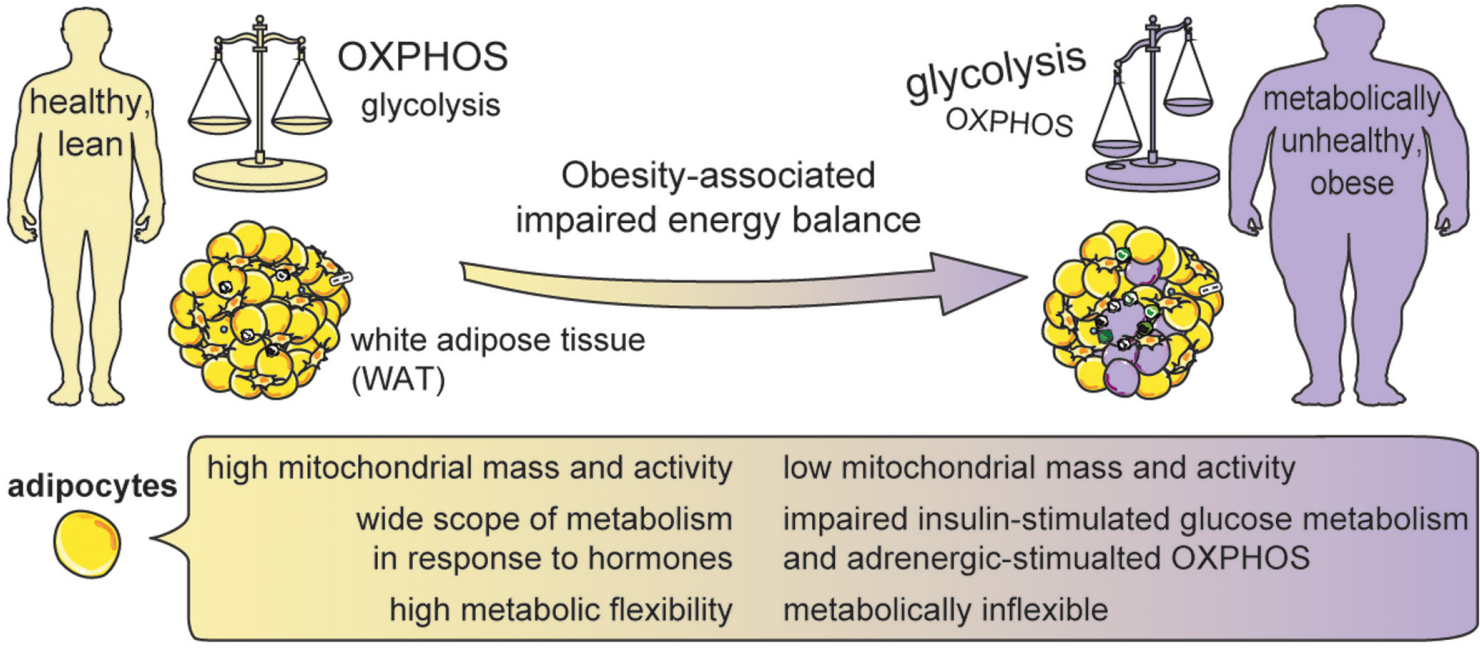

\section{Figure 3}

Obesity-associated impaired energy metabolism in white adipocytes. In lean WAT, high mitochondrial mass and activity in adipocytes allow for high metabolic flexibility. OXPHOS and glycolysis are adjusted in response to hormonal regulation (insulin and adrenergic activation). Visceral adipocytes display lower mitochondrial activity than subcutaneous adipocytes (normalize per cell and mitochondrial content). Contrasting lean WAT, obese WAT is characterized by lower mitochondrial mass and activity, impaired glucose metabolism and dampened hormonal responses. Obesity overall renders adipocytes metabolically inflexible.

https://ec.bioscientifica.com https://doi.org/10.1530/EC-19-0016
(C) 2019 The authors Published by Bioscientifica Ltd

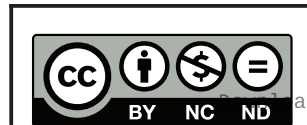

This work is licensed under a Creative Commons Attribution-NonCommercial-NoDerivatives 4.0 Internationab License.ifica com at $04 / 26 / 2023$ 08:03:11AM 
lower adrenergic-stimulated OXPHOS. Therefore, it is not surprising that unhealthy adipocytes are less metabolically flexible.

\section{Linking ATMФ to human adipocyte bioenergetics}

Metabolically healthy (vs unhealthy) obesity is characterized by dampened inflammatory molecular signatures in WAT and lower levels of circulating inflammation markers (TNF $\alpha$ and hCRP) (121, 122, 123, 124). Together, this indicates the link between inflammation and dysregulated metabolism. Early observations by Weisberg et al. that showed obesityassociated increases in ATM $\Phi$ content, also reported on the decreased expression of several mitochondria-related genes (24). Cytokines are potential candidates mediating the crosstalk between ATM $\Phi$ and the energy metabolism of adipocytes (Fig. 4). Typical cytokines involved in WAT inflammation are TNF $\alpha$, IL6 and IL1 $\beta$. These cytokines promote insulin resistance and/or induce lipolysis $(125,126,127,128)$. Notably, some of these and other cytokines suppress mitochondrial function (22) (Fig. 4B). The crosstalk between ATM $\Phi$ and adipocytes is certainly bidirectional, and dysfunctional adipose mitochondria possibly promote WAT inflammation as well (129). This review, however, will focus on the effects of ATM $\Phi$ in controlling adipocyte mitochondria.
In vivo, the paracrine interactions between ATM $\Phi$ and adipose cells are complex, as M $\Phi$ are very dynamic cells with a changing cytokine profile that is influenced by adipokines $(130,131)$, sympathetic nerve activation (132), as well as insulin and nutrients (83). ATMФ could represent a distinct subpopulation in WAT with a unique, not yet fully characterized phenotype that is altered during obesity (as discussed in the sections above). Thus, studying ex vivo the effects of $\mathrm{M} \Phi$-conditioned media, which represent the global secretome of $M \Phi$, provides only a rudimentary picture of the effects that MФ-derived products impose on fat cell bioenergetics. This ex vivo system, however, enables us to identify the factors, signaling pathways and mechanisms that can be further investigated and targeted in vivo to modulate mitochondrial function of adipocytes.

\section{ATM $\Phi$ and secreted factors affect glucose metabolism/glycolysis of adipocytes}

Using conditioned media from LPS-activated MФ (MФ$\mathrm{CM})$, Lumeng et al. observed higher basal glucose uptake in adipocytes in a murine cell culture system (3T3-L1 adipocytes and RAW264.7 or J774 macrophages) (133). In line with this, we demonstrated higher glycolytic activity in adipocytes after incubation with either LPS/INF $\gamma$-activated MФ-CM or IL10/TGF $\beta$-activated MФ-CM (34), using a human model system composed of SGBS cells, a human subcutaneous adipocyte model

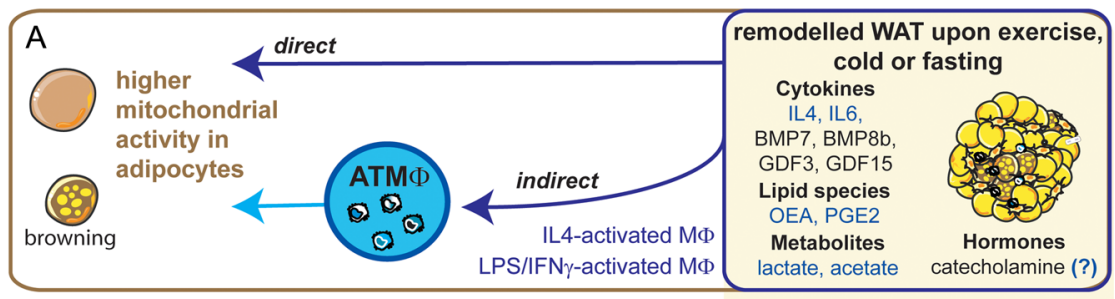

WAT-specific environment

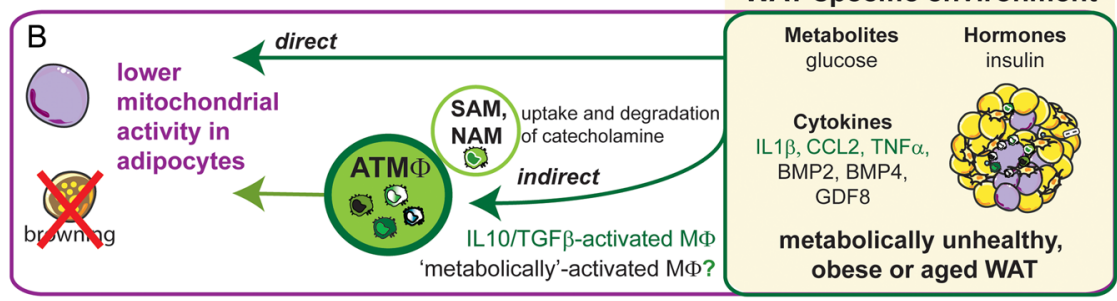

Figure 4

Control of adipocyte energy metabolism. In the WAT-specific environment (yellow background), multiple cytokines/chemokines, metabolites, lipid species and hormones from diverse cell types within WAT and/or circulation can exert either positive (upper box, A) or negative (lower box, B) effects on WAT metabolism. These factors control mitochondrial function of (pre-)adipocytes either directly and/or indirectly by first affecting the ATMФ secretion profile. Notably, the composition of released factors depends on M $\Phi$ activation (known for factors written in blue/green). Depending on the TGF $\beta$ superfamily (BMPs and GDFs), WAT metabolism is either promoted or suppressed. A recently identified but controversially discussed mechanism of M $\Phi$ invoked browning and enhanced WAT metabolism is the secretion of catecholamine by IL4-activated MФ during cold and exercise (upper box, A). On the contrary, NAMs/SAMs (lower box, $B)$, which represent $M \Phi$ in close proximity of neurons/axons, may reduce local catecholamine levels and thus suppress mitochondrial function of adipocytes with age and obesity. https://ec.bioscientifica.com https://doi.org/10.1530/EC-19-0016 (c) 2019 The authors Published by Bioscientifica Ltd

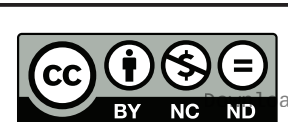

This work is licensed under a Creative Commons Attribution-NonCommercial-NoDerivatives 4.0 Internationab License.ifica com at $04 / 26 / 2023$ 08:03:11AM 
and THP1 cells, a human monocytic cell line that can be differentiated into $\mathrm{M} \Phi$ and subsequently activated with different stimuli (134). Overall, АTM $\Phi$ possess the potential to increase basal glucose uptake in adipocytes. The potential responsible factors comprise the classical inflammatory cytokines which are associated with obese WAT inflammation, such as TNF $\alpha$ and IL1 $\beta$. Controversial reports exist for IL6, which is a cytokine that has often been associated with WAT inflammation $(22,57,135)$. Furthermore, a few studies report on reduced insulinstimulated glucose uptake after exposing adipocytes to either different $\mathrm{M} \Phi-\mathrm{CM}$, or to cytokines, such as TNF $\alpha$, CCL2 and IL1 $\beta$, which are mostly linked to the decreased activation of insulin signaling cascades $(35,128,133,136$, 137). Of note, many studies show the percentage or foldchanges of glucose uptake vs vehicle (0 nM insulin), not fully excluding the possibility that the reduced response in these studies may be due to increased basal glucose uptake, at least partially.

\section{The molecular identity of ATM $\Phi$ released factors reducing adipose energy metabolism}

Maintenance of cellular homeostasis requires a constant production of ATP unless specific, energy-demanding tasks are performed. Therefore, increased basal glucose uptake may report increased energy demand. However, increased basal glucose uptake may equally report a compensatory mechanism to counter fit decreased OXPHOS activity (ATP-linked respiration). The latter scenario describes a switch in the energy producing pathways, rather than the increase in metabolic activity. IL10/TGF $\beta$-activated M $\Phi$ and/or IL1 $\beta$ promote such a metabolic switch in adipocytes by increasing glucose uptake/glycolysis while simultaneously decreasing mitochondrial activity $(22,34)$ (Fig. 4B). IL1 $\beta$ also inhibits cAMP- and isoproterenol-induced PGC1a and UCP1 mRNA levels $(138,139)$, further supporting the IL1 $\beta$ signaling pathway in suppressing oxidative metabolism of adipocytes. TNF $\alpha$ represents a cytokine that appears to reduce major energy-producing pathways, glycolysis and OXPHOS. The lowering in production of cellular energy subsequently results in adipocyte death, finally seen as the loss of mitochondrial membrane potential and cleaved caspase-3 (22). Notably, TNF $\alpha$ levels and mitochondrial mass correlate negatively in human WAT $(129,140)$. Whether the secretome of the 'metabolically' activated MФ in obese WAT (83) is significantly involved in decreased adipose mitochondrial function is not known as yet (Fig. 4B).
ATM $\Phi$ and their secreted factors may, however, not only directly affect adipocyte energy metabolism, but also indirectly by altering neuronal signals into the tissue. One of those signals is catecholamine, which enhances energy dissipation. Two mechanisms have been described how M $\Phi$ may limit bioactive catecholamine in WAT and brown adipose tissue (BAT): One mechanism proposes the inhibition of neuronal innervation. BAT-specific M $\Phi$ inhibit sympathetic neuronal innervation and thereby impair catecholamine signaling in BAT, while WAT innervation is not affected (141). The other mechanism proposes neurotransmitter clearance. A distinct $\mathrm{M} \Phi$-type that is attached, or at least in close proximity, to axons of the SNS takes up and degrades norepinephrine (NE). These M $\Phi$ have been termed either sympathetic neuronassociated M $($ (SAMs) (30) or nerve-associated M $\Phi$ (NAMs) (142). So far, SAMs/NAMs have been identified in murine viscWAT (142) and scWAT (30), but not unequivocally in murine BAT (30). SAMs/NAMs may regulate local catecholamine concentrations and prevent catecholamine spill over into the circulation $(30,142,143)$. The $\mathrm{M} \Phi$ mediated NE uptake and degradation system is apparently enhanced during obesity (increased number of SAMs (30)) and aging (GDF3-dependent increased expression of genes controlling NE degrading in NAMs (142)), and potentially contribute to decreased energy metabolism with age and obesity (Fig. 4B).

\section{Mediators between ATM $\Phi$ and increased adipose energy metabolism}

The interaction between ATM $\Phi$ and increased WAT energy metabolism is supported by mouse models that claim the involvement of $\mathrm{M} \Phi$ in the 'browning' of WAT upon cold exposure, exercise and caloric restriction $(26,27,28$, 144, 145) (Fig. 4A). Browning of WAT has been classically defined as the upregulation of uncoupling protein 1 (UCP1) and the appearance of multilocular adipocytes in WAT, termed beige adipocytes. Beige adipocytes associate with mitochondrial biogenesis and higher energy turnover. UCP1 resides in the mitochondrial inner membrane and uncouples the proton motive force from ATP synthesis, thereby directly releasing energy as heat and accelerating catabolic processes. With this energy-burning machinery, the browning of WAT can restore dysregulated glucose and lipid metabolism in diverse obese and diabetic mouse models $(26,27,28,146)$. With these observations in mouse models, browning-inducing pathways have gained remarkable attention in biomedicine to treat metabolic diseases. In the context of browning, АTM $\Phi$ may release 
cytokines, which could induce UCP1 expression, higher energy turnover and energy wasting in adipocytes (Fig. 4A). Several publications implicate IL6 signaling in beige adipocyte formation and WAT browning $(147,148$, 149), but some aspects of IL6-stimulated glucose uptake are controversial $(147,148,149,150)$.

Another cytokine that affects WAT energy metabolism, either directly or via M $\Phi$, is IL4 (Fig. 4A). IL4 is secreted by $\mathrm{M} \Phi$ and to a higher extent by eosinophils in WAT (26). It may directly control WAT metabolism, by acting either on preadipocytes to promote differentiation into beige adipocytes, or on adipocytes to induce higher ATP turnover (151, 152). Several publications place IL4-activated M $\Phi$ into immune signaling cascades that are able to induce UCP1 expression and mitochondrial activity in adipocytes. The IL4-M $\Phi$ axis can be modulated by additional factors of endocrine (e.g. released distantly from muscle (27)) and/or paracrine nature (e.g. released adjacently from other WAT cell types, including eosinophils, type 2 innate lymphoid cells, regulatory and natural killer T cells (26, $153,154)$ ). The underlying mechanisms how the IL4$\mathrm{M} \Phi$ system induces browning is not fully understood. In particular, the involvement of catecholamine-producing ATM $\Phi$ is controversially discussed $(28,29)$. Although some reports on catecholamine synthesis in M $\Phi$ exist $(143,155$, $156)$, the physiological contribution during cold-induced thermogenesis seems to be of minor importance (29). Whether M $\Phi$-mediated uptake (143) or degradation of catecholamines (as shown for SAMs/NAMs $(30,142)$ ) is inhibited and substantially contributes to cold-induced WAT browning requires further investigations.

Additional candidates that impact mitochondrial function in adipocytes belong to the TGF $\beta$ superfamily. TGF 33 inhibits the 'browning' of WAT and stimulates proliferation of white adipocytes $(150,157,158,159)$. Our functional work demonstrated that IL10/TGF $\beta$-activated M $\Phi$ secreted factors decrease ATP-linked respiration in human subcutaneous adipocytes, thus providing evidence for indirect suppression of mitochondrial respiration by TGF $\beta$ (34). Several other members of the TGF $\beta$ superfamily have been proposed in the regulation of oxidative metabolism in adipocytes and the browning of WAT, affecting whole body energy metabolism. Many of these factors are indeed secreted by $M \Phi$. Whether these factors promote or suppress energy metabolism depends on the distinct factor or receptor, as well as on the adipose depot (BAT or WAT). Examples for specific effects include bone morphogenetic proteins (BMP 2, 4, 7 and $8 b)(160,161,162,163,164,165,166)$ and growth differentiation factors (GDF 1, 3, 5, 15) $(142,167,168$,
169, 170, 171, 172) (Fig. 4A and B). The effects also depend on the developmental stage of the adipocytes, whether the cytokine acts directly on the mesenchymal stem cell, on the early committed preadipocytes (brown, beige or white) or on the adipocytes, or whether the cytokine acts indirectly by changing $M \Phi$ infiltration and their phenotype $(170,173)$. Additionally, there are reports that these cytokines act on the central nervous system to control metabolism $(164,174)$.

Other mediators between ATM $\Phi$ and adipocyte metabolism are metabolites. Upon activation, $\mathrm{M} \Phi$ change their metabolomic profile $(175,176)$, for example upon LPS activation, more lactate and pyruvate are released (176). Lactate and acetate have been suggested as inducers of WAT browning $(177,178,179)$. Lipid mediators (e.g. oleoylethanolamine (OEA), prostaglandin E2 (PGE2)) are differentially released by $\mathrm{M} \Phi$, depending on the mode of activation (180, 181, 182). Circulating metabolites and lipid mediators are involved in the browning of rodent WAT $(177,183,184)$, indicating that these factors represent additional candidates by which $M \Phi$ modulate mitochondrial activity in white adipocytes (Fig. 4A). Although $\mathrm{M} \Phi$ may not be the main source for some cytokines or factors that have been linked to increased or decreased energy expenditure in WAT (e.g. IFN $\gamma$, retinoic acid, catecholamine, IL17, lactate), the indirect involvement of these factors cannot be formally excluded $(29,34,185,186,187,188)$. For instance, we have recently found increased ATP-linked respiration in white adipocytes after exposure to the secreted factors of LPS/IFN $\gamma$-activated MФ (34) (Fig. 4A).

In summary (Fig. 4), АTM $\Phi$ can be activated by the WAT-specific microenvironment which is impacted by circulating endocrine and auto-/paracrine factors (cytokines, nutrients and hormones). Thus, the WATspecific environment is characterized by distinctly activated ATM $\Phi$ and $\mathrm{M} \Phi$-secreted factors which contribute to the microenvironment but furthermore and the regulation of WAT energy metabolism. During cold, exercise and fasting, the induction of adipose energy metabolism by enhancing beige adipocyte differentiation, inducing UCP1 expression, increasing ATP turnover and/or increasing energy dissipating pathways such as catecholamine can be mediated by activated M $\Phi$ (e.g. LPS/IFN $\gamma$ - or IL4-activated M $\Phi$ ) and M $\Phi$ released factors such as cytokines (IL4, IL6), metabolites (lactate, acetate) and/or lipid mediators (PGE2, OEA) (Fig. 4A). In the obese state, other activated M $\Phi$ (e.g. IL10/TGF $\beta$ - or 'metabolically' activated $\mathrm{M} \Phi$ ) and $\mathrm{M} \Phi$ released factors such as cytokines (e.g. IL1 $\beta$ and TNF $\alpha$ ) may decrease energy

This work is licensed under a Creative Commons Attribution-NonCommercial-NoDerivatives 4.0 Internationab ticense.ifica com at $04 / 26 / 2023$ 08:03:11AM 
metabolism of adipocytes or limit local energy dissipating pathways by uptake and degradation of catecholamine (by SAM, NAM) (Fig. 4B). Several scenarios how these factors operate are conceivable, and they most likely overlap and work in concert, by direct action on mesenchymal stem cells, preadipocytes and adipocytes and by indirect signals via $\mathrm{M} \Phi$. Indirect action may also occur via additional cell types in WAT, including other immune cells (e.g. T cells), epithelial cells and neurons (not depicted in Fig. 4).

\section{Conclusion and outlook}

In the upcoming field of immunometabolism, which investigates the crosstalk between immune cell function and metabolic homeostasis, the understanding on paracrine regulation of human white adipocyte metabolism by ATM $\Phi$, is utterly important. By identifying the ATM $\Phi$-secreted factors that control mitochondrial function and energy metabolism in adipocytes, we may be able to find novel therapeutic targets to treat diseased WAT during obesity. This new understanding of the metabolic network in WAT needs to be resolved on the molecular level, investigating how controlling pathways are regulated under physiological and pathophysiological conditions. A detailed investigation is required on the ATM $\Phi$ phenotypes/subpopulations and how fat depot-, gender- and age-specific ATM $\Phi$ infiltration and activation are related to adipocytes, WAT and whole body metabolism in health and disease. Although this review focuses on the paracrine action of $M \Phi$ within the white adipose tissue, it should be considered that ATM $\Phi$ contribute to the overall secretion profile of WAT with factors that are released into the circulation for endocrine action causing systemic effects such as insulin resistance. It is feasible to speculate that these factors will not only impact the energy metabolism of adipocytes, but also as endocrine factors potentially impact the bioenergetics of other more distantly located target cells (such as hepatocytes and myocytes).

Furthermore, not only $\mathrm{M} \Phi$ composition changes with obesity, but other immune cells, such as T cell, B cell, eosinophil, iNKT and neutrophils change in number and activation state, contributing to the impaired immune balance in obese WAT. Thus, the complex microenvironment of adipose tissue that controls the bioenergetics of adipocytes is composed of multiple cytokines and cell types with multiple cellular targets. Additionally, there is potentially a feed-back mechanism in place where adipocyte-secreted proteins and signals impact the immune cell secretome that in turn controls adipocyte metabolism. How the endocrine and nervous system that regulates metabolism (e.g. catecholamine, acetylcholine, insulin and glucagon) affects the crosstalk of ATM $\Phi$ and fat cells represents another promising research topic. Many other aspects require further investigation, concerning cytokine production and combinatorial effects on adipocytes, the interaction with energy storing and dissipating pathways, as well as the crosstalk between adipocytes and cell types other than ATM $\Phi$ to control adipocyte glycolysis and mitochondrial function.

Owing to the profound differences in the immune system between mice and humans, it is of major importance to consolidate murine pathways and their impact on metabolism in humans. That said, however, it is promising that certain activated $\mathrm{M} \Phi$ not only induce energy-producing pathways (glycolysis and OXPHOS) in white adipocytes, but possibly in an UCP1-independent manner, suggesting new options to increase energy expenditure by targeting inflammatory pathways in WAT. Novel strategies in obesity therapy are required as obese and older subjects are usually characterized by the absence or low content of BAT (UCP1+-cells) (189). Whether the browning capacity of human subcutaneous WAT can be enhanced to that extent that it eventually contributes significantly to systemic energy expenditure, is still an open question $(190,191)$. Beyond energy wasting in adipocytes, mitochondria are crucial for all cellular pathways (e.g. differentiation, apoptosis, energy dissipation, adipokine secretion), thus representing ubiquitous targets to treat obesity and its associated disorders. Collectively, targeting inflammatory pathways in fat depots could be a feasible strategy for the treatment of metabolic diseases.

\section{Declaration of interest}

The author declares that there is no conflict of interest that could be perceived as prejudicing the impartiality of this review.

\section{Funding}

The original work of M K was supported by the German Center for Diabetes Research (DZD) and the German Diabetes Association (DDG).

\section{Acknowledgments}

The author would like to thank Martin Jastroch for helpful comments on the manuscript and proofreading. Figures were created using modified components from Servier Medical Art (https://smart.servier.com). (c) 2019 The authors Published by Bioscientifica Ltd
This work is licensed under a Creative Commons Attribution-NonCommercial-NoDerivatives 4.0 Internationab sicense.ifica . com at 04/26/2023 08:03:11AM 


\section{References}

1 Jansson PA, Larsson A, Smith U \& Lönnroth P. Lactate release from the subcutaneous tissue in lean and obese men. Journal of Clinical Investigation 199493 240-246. (https://doi.org/10.1172/JCI116951)

2 Kershaw EE \& Flier JS. Adipose tissue as an endocrine organ. Journal of Clinical Endocrinology and Metabolism 200489 2548-2556. (https:// doi.org/10.1210/jc.2004-0395)

3 Trayhurn P. Endocrine and signalling role of adipose tissue: new perspectives on fat. Acta Physiologica Scandinavica 2005184 285-293. (https://doi.org/10.1111/j.1365-201X.2005.01468.x)

4 Kaaman M, Sparks LM, van Harmelen V, Smith SR, Sjölin E, Dahlman I \& Arner P. Strong association between mitochondrial DNA copy number and lipogenesis in human white adipose tissue. Diabetologia 200750 2526-2533. (https://doi.org/10.1007/s00125007-0818-6)

5 Kusminski CM \& Scherer PE. Mitochondrial dysfunction in white adipose tissue. Trends in Endocrinology and Metabolism 201223 435-443. (https://doi.org/10.1016/j.tem.2012.06.004)

6 Koh EH, Park JY, Park HS, Jeon MJ, Ryu JW, Kim M, Kim SY, Kim MS, Kim SW, Park IS, et al. Essential role of mitochondrial function in adiponectin synthesis in adipocytes. Diabetes $2007562973-2981$. (https://doi.org/10.2337/db07-0510)

7 Wang $\mathrm{CH}$, Wang CC, Huang HC \& Wei YH. Mitochondrial dysfunction leads to impairment of insulin sensitivity and adiponectin secretion in adipocytes. FEBS Journal 2013280 1039-1050. (https://doi.org/10.1111/febs.12096)

8 Szkudelski T, Nogowski L \& Szkudelska K. Short-term regulation of adiponectin secretion in rat adipocytes. Physiological Research 2011 $60521-530$.

9 Yin X, Lanza IR, Swain JM, Sarr MG, Nair KS \& Jensen MD. Adipocyte mitochondrial function is reduced in human obesity independent of fat cell size. Journal of Clinical Endocrinology and Metabolism 201499 E209-E216. (https://doi.org/10.1210/jc.2013-3042)

10 Heinonen S, Buzkova J, Muniandy M, Kaksonen R, Ollikainen M, Ismail K, Hakkarainen A, Lundbom J, Lundbom N, Vuolteenaho K, et al. Impaired mitochondrial biogenesis in adipose tissue in acquired obesity. Diabetes 201564 3135-3145. (https://doi.org/10.2337/db14-1937)

11 Pietiläinen KH, Naukkarinen J, Rissanen A, Saharinen J, Ellonen P, Keränen H, Suomalainen A, Götz A, Suortti T, Yki-Järvinen H, et al. Global transcript profiles of fat in monozygotic twins discordant for BMI: pathways behind acquired obesity. PLoS Medicine 20085 e51. (https://doi.org/10.1371/journal.pmed.0050051)

12 Fischer B, Schöttl T, Schempp C, Fromme T, Hauner H, Klingenspor M \& Skurk T. Inverse relationship between body mass index and mitochondrial oxidative phosphorylation capacity in human subcutaneous adipocytes. American Journal of Physiology: Endocrinology and Metabolism 2015309 E380-E387. (https://doi. org/10.1152/ajpendo.00524.2014)

13 Yehuda-Shnaidman E, Buehrer B, Pi J, Kumar N \& Collins S. Acute stimulation of white adipocyte respiration by PKA-induced lipolysis. Diabetes 201059 2474-2483. (https://doi.org/10.2337/db10-0245)

14 Hotamisligil GS, Shargill NS \& Spiegelman BM. Adipose expression of tumor necrosis factor-alpha: direct role in obesity-linked insulin resistance. Science 1993259 87-91. (https://doi.org/10.1126/ science.7678183)

15 Xu H, Barnes GT, Yang Q, Tan G, Yang D, Chou CJ, Sole J, Nichols A, Ross JS, Tartaglia LA, et al. Chronic inflammation in fat plays a crucial role in the development of obesity-related insulin resistance. Journal of Clinical Investigation 2003112 1821-1830. (https://doi. org/10.1172/JCI19451)

16 Cai D, Yuan M, Frantz DF, Melendez PA, Hansen L, Lee J \& Shoelson SE. Local and systemic insulin resistance resulting from hepatic activation of IKK-beta and NF-kappaB. Nature Medicine 2005 11 183-190. (https://doi.org/10.1038/nm1166)
17 Lanthier N, Molendi-Coste O, Horsmans Y, van Rooijen N, Cani PD \& Leclercq IA. Kupffer cell activation is a causal factor for hepatic insulin resistance. American Journal of Physiology: Gastrointestinal and Liver Physiology 2010298 G107-G116. (https://doi.org/10.1152/ ajpgi.00391.2009)

18 Saghizadeh M, Ong JM, Garvey WT, Henry RR \& Kern PA. The expression of TNF alpha by human muscle. Relationship to insulin resistance. Journal of Clinical Investigation 199697 1111-1116. (https://doi.org/10.1172/JCI118504)

19 De Souza CT, Araujo EP, Bordin S, Ashimine R, Zollner RL, Boschero AC, Saad MJ \& Velloso LA. Consumption of a fat-rich diet activates a proinflammatory response and induces insulin resistance in the hypothalamus. Endocrinology 2005146 4192-4199. (https:// doi.org/10.1210/en.2004-1520)

20 Ehses JA, Perren A, Eppler E, Ribaux P, Pospisilik JA, Maor-Cahn R, Gueripel X, Ellingsgaard H, Schneider MKJ, Biollaz G, et al. Increased number of islet-associated macrophages in type 2 diabetes. Diabetes 200756 2356-2370. (https://doi.org/10.2337/db06-1650)

21 Bondia-Pons I, Ryan L \& Martinez JA. Oxidative stress and inflammation interactions in human obesity. Journal of Physiology and Biochemistry 201268 701-711. (https://doi.org/10.1007/s13105-0120154-2)

22 Hahn WS, Kuzmicic J, Burrill JS, Donoghue MA, Foncea R, Jensen MD, Lavandero S, Arriaga EA \& Bernlohr DA. Proinflammatory cytokines differentially regulate adipocyte mitochondrial metabolism, oxidative stress, and dynamics. American Journal of Physiology: Endocrinology and Metabolism 2014306 E1033-E1045. (https://doi.org/10.1152/ajpendo.00422.2013)

23 Qatanani M, Tan Y, Dobrin R, Greenawalt DM, Hu G, Zhao W, Olefsky JM, Sears DD, Kaplan LM \& Kemp DM. Inverse regulation of inflammation and mitochondrial function in adipose tissue defines extreme insulin sensitivity in morbidly obese patients. Diabetes 2013 62 855-863. (https://doi.org/10.2337/db12-0399)

24 Weisberg SP, McCann D, Desai M, Rosenbaum M, Leibel RL \& Ferrante AW. Obesity is associated with macrophage accumulation in adipose tissue. Journal of Clinical Investigation 2003112 1796-1808. (https://doi.org/10.1172/JCI19246)

25 Wernstedt Asterholm I, Tao C, Morley TS, Wang QA, DelgadoLopez F, Wang ZV \& Scherer PE. Adipocyte inflammation is essential for healthy adipose tissue expansion and remodeling. Cell Metabolism 201420 103-118. (https://doi.org/10.1016/j. cmet.2014.05.005)

26 Qiu Y, Nguyen KD, Odegaard JI, Cui X, Tian X, Locksley RM, Palmiter RD \& Chawla A. Eosinophils and type 2 cytokine signaling in macrophages orchestrate development of functional beige fat. Cell 2014157 1292-1308. (https://doi.org/10.1016/j.cell.2014.03.066)

27 Rao RR, Long JZ, White JP, Svensson KJ, Lou J, Lokurkar I, Jedrychowski MP, Ruas JL, Wrann CD, Lo JC, et al. Meteorin-like is a hormone that regulates immune-adipose interactions to increase beige fat thermogenesis. Cell 2014157 1279-1291. (https://doi. org/10.1016/j.cell.2014.03.065)

28 Nguyen KD, Qiu Y, Cui X, Goh YPS, Mwangi J, David T, Mukundan L, Brombacher F, Locksley RM \& Chawla A. Alternatively activated macrophages produce catecholamines to sustain adaptive thermogenesis. Nature 2011480 104-108. (https://doi.org/10.1038/ nature10653)

29 Fischer K, Ruiz HH, Jhun K, Finan B, Oberlin DJ, van der Heide V, Kalinovich AV, Petrovic N, Wolf Y, Clemmensen C, et al. Alternatively activated macrophages do not synthesize catecholamines or contribute to adipose tissue adaptive thermogenesis. Nature Medicine 201723 623-630. (https://doi.org/10.1038/nm.4316)

30 Pirzgalska RM, Seixas E, Seidman JS, Link VM, Sánchez NM, Mahú I, Mendes R, Gres V, Kubasova N, Morris I, et al. Sympathetic neuronassociated macrophages contribute to obesity by importing and metabolizing norepinephrine. Nature Medicine 201723 1309-1318. (https://doi.org/10.1038/nm.4422) 
31 Feng J, Li L, Ou Z, Li Q, Gong B, Zhao Z, Qi W, Zhou T, Zhong J, Cai W, et al. IL-25 stimulates M2 macrophage polarization and thereby promotes mitochondrial respiratory capacity and lipolysis in adipose tissues against obesity. Cellular and Molecular Immunology 201815 493-505. (https://doi.org/10.1038/cmi.2016.71)

32 Qian SW, Wu MY, Wang YN, Zhao YX, Zou Y, Pan JB, Tang Y, Liu Y, Guo L \& Tang QQ. BMP4 facilitates beige fat biogenesis via regulating adipose tissue macrophages. Journal of Molecular Cell Biology 201911 14-25. (https://doi.org/10.1093/jmcb/mjy011)

33 Lee YH, Kim SN, Kwon HJ, Maddipati KR \& Granneman JG. Adipogenic role of alternatively activated macrophages in $\beta$-adrenergic remodeling of white adipose tissue. American Journal of Physiology: Regulatory, Integrative and Comparative Physiology 2016310 R55-R65. (https://doi.org/10.1152/ajpregu.00355.2015)

34 Keuper M, Sachs S, Walheim E, Berti L, Raedle B, Tews D, FischerPosovszky P, Wabitsch M, Hrabě de Angelis M, Kastenmüller G, et al. Activated macrophages control human adipocyte mitochondrial bioenergetics via secreted factors. Molecular Metabolism 20176 1226-1239. (https://doi.org/10.1016/j.molmet.2017.07.008)

35 Keuper M, Blüher M, Schön MR, Möller P, Dzyakanchuk A, Amrein K, Debatin KM, Wabitsch M \& Fischer-Posovszky P. An inflammatory micro-environment promotes human adipocyte apoptosis. Molecular and Cellular Endocrinology 2011339 105-113. (https://doi. org/10.1016/j.mce.2011.04.004)

36 Ehrlund A, Acosta JR, Björk C, Hedén P, Douagi I, Arner P \& Laurencikiene J. The cell-type specific transcriptome in human adipose tissue and influence of obesity on adipocyte progenitors. Scientific Data 20174 170164. (https://doi.org/10.1038/ sdata.2017.164)

37 Cancello R, Henegar C, Viguerie N, Taleb S, Poitou C, Rouault C, Coupaye M, Pelloux V, Hugol D, Bouillot JL, et al. Reduction of macrophage infiltration and chemoattractant gene expression changes in white adipose tissue of morbidly obese subjects after surgery-induced weight loss. Diabetes 200554 2277-2286. (https:// doi.org/10.2337/diabetes.54.8.2277)

38 Duffaut C, Zakaroff-Girard A, Bourlier V, Decaunes P, Maumus M, Chiotasso P, Sengenès C, Lafontan M, Galitzky J \& Bouloumié A. Interplay between human adipocytes and $\mathrm{T}$ lymphocytes in obesity: CCL20 as an adipochemokine and T lymphocytes as lipogenic modulators. Arteriosclerosis, Thrombosis, and Vascular Biology 200929 1608-1614. (https://doi.org/10.1161/ATVBAHA.109.192583)

39 Curat CA, Miranville A, Sengenès C, Diehl M, Tonus C, Busse R $\&$ Bouloumié A. From blood monocytes to adipose tissueresident macrophages induction of diapedesis by human mature adipocytes. Diabetes 200453 1285-1292. (https://doi.org/10.2337/ diabetes.53.5.1285)

40 Curat CA, Wegner V, Sengenès C, Miranville A, Tonus C, Busse R $\&$ Bouloumié A. Macrophages in human visceral adipose tissue: increased accumulation in obesity and a source of resistin and visfatin. Diabetologia 200649 744-747. (https://doi.org/10.1007/ s00125-006-0173-z)

41 Koppaka S, Kehlenbrink S, Carey M, Li W, Sanchez E, Lee DE, Lee H, Chen J, Carrasco E, Kishore P, et al. Reduced adipose tissue macrophage content is associated with improved insulin sensitivity in thiazolidinedione-treated diabetic humans. Diabetes 201362 1843-1854. (https://doi.org/10.2337/db12-0868)

42 van Harmelen V, Skurk T, Röhrig K, Lee YM, Halbleib M, AprathHusmann I \& Hauner H. Effect of BMI and age on adipose tissue cellularity and differentiation capacity in women. International Journal of Obesity and Related Metabolic Disorders 200327 889-895. (https://doi.org/10.1038/sj.ijo.0802314)

43 Zimmerlin L, Donnenberg VS, Pfeifer ME, Meyer EM, Péault B, Rubin JP \& Donnenberg AD. Stromal vascular progenitors in adult human adipose tissue. Cytometry: Part A 201077 22-30. (https://doi. $\operatorname{org} / 10.1002 /$ cyto.a.20813)
44 Klar AS, Güven S, Zimoch J, Zapiórkowska NA, Biedermann T, Böttcher-Haberzeth S, Meuli-Simmen C, Martin I, Scherberich A, Reichmann E, et al. Characterization of vasculogenic potential of human adipose-derived endothelial cells in a three-dimensional vascularized skin substitute. Pediatric Surgery International 201632 17-27. (https://doi.org/10.1007/s00383-015-3808-7)

45 Glastonbury CA, Couto Alves A, El-Sayed Moustafa J \& Small KS. Cell-type heterogeneity in adipose tissue is associated with complex traits and reveals disease-relevant cell-specific eQTLs. American Journal of Human Genetics 2019 [epub]. (https://doi.org/10.1016/j. ajhg.2019.03.025)

46 Travers RL, Motta AC, Betts JA, Bouloumié A \& Thompson D. The impact of adiposity on adipose tissue-resident lymphocyte activation in humans. International Journal of Obesity 201539 762-769. (https:// doi.org/10.1038/ijo.2014.195)

47 Harman-Boehm I, Blüher M, Redel H, Sion-Vardy N, Ovadia S, Avinoach E, Shai I, Klöting N, Stumvoll M, Bashan N, et al. Macrophage infiltration into omental versus subcutaneous fat across different populations: effect of regional adiposity and the comorbidities of obesity. Journal of Clinical Endocrinology and Metabolism 200792 2240-2247. (https://doi.org/10.1210/jc.2006-1811)

48 Bruun JM, Lihn AS, Pedersen SB \& Richelsen B. Monocyte chemoattractant protein-1 release is higher in visceral than subcutaneous human adipose tissue (AT): implication of macrophages resident in the AT. Journal of Clinical Endocrinology and Metabolism 200590 2282-2289. (https://doi.org/10.1210/jc.20041696)

49 Cancello R, Tordjman J, Poitou C, Guilhem G, Bouillot JL, Hugol D, Coussieu C, Basdevant A, Hen AB, Bedossa P, et al. Increased infiltration of macrophages in omental adipose tissue is associated with marked hepatic lesions in morbid human obesity. Diabetes 2006 55 1554-1561. (https://doi.org/10.2337/db06-0133)

50 Spencer M, Yao-Borengasser A, Unal R, Rasouli N, Gurley CM, Zhu B, Peterson CA \& Kern PA. Adipose tissue macrophages in insulinresistant subjects are associated with collagen VI and fibrosis and demonstrate alternative activation. American Journal of Physiology: Endocrinology and Metabolism 2010299 E1016-E1027. (https://doi. org/10.1152/ajpendo.00329.2010)

51 Blaszczak AM, Jalilvand A, Liu J, Wright VP, Suzo A, Needleman B, Noria S, Lafuse W, Hsueh WA \& Bradley D. Human visceral adipose tissue macrophages are not adequately defined by standard methods of characterization. Journal of Diabetes Research 20192019 1-7. (https://doi.org/10.1155/2019/8124563)

52 Laparra A, Tricot S, Le Van M, Damouche A, Gorwood J, Vaslin B, Favier B, Benoist S, Ho Tsong Fang R, Bosquet N, et al. The frequencies of immunosuppressive cells in adipose tissue differ in human, non-human primate, and mouse models. Frontiers in Immunology 201910 117. (https://doi.org/10.3389/ fimmu.2019.00117)

53 Renovato-Martins M, Matheus ME, de Andrade IR, Moraes JA, da Silva SV, Citelli dos Reis M, de Souza AAP, da Silva CC, Bouskela E \& Barja-Fidalgo C. Microparticles derived from obese adipose tissue elicit a pro-inflammatory phenotype of CD16+, CCR5+ and TLR8+ monocytes. Biochimica et Biophysica Acta (BBA): Molecular Basis of Disease 20171863 139-151. (https://doi.org/10.1016/j. bbadis.2016.09.016)

54 Weisberg SP, Hunter D, Huber R, Lemieux J, Slaymaker S, Vaddi K, Charo I, Leibel RL \& Ferrante AW. CCR2 modulates inflammatory and metabolic effects of high-fat feeding. Journal of Clinical Investigation 2006116 115-124. (https://doi.org/10.1172/JCI24335)

55 Kanda H, Tateya S, Tamori Y, Kotani K, Hiasa K, Kitazawa R, Kitazawa S, Miyachi H, Maeda S, Egashira K, et al. MCP-1 contributes to macrophage infiltration into adipose tissue, insulin resistance, and hepatic steatosis in obesity. Journal of Clinical Investigation 2006116 1494-1505. (https://doi.org/10.1172/JCI26498) https://ec.bioscientifica.com https://doi.org/10.1530/EC-19-0016 (c) 2019 The authors Published by Bioscientifica Ltd
This work is licensed under a Creative Commons Attribution-NonCommercial-NoDerivatives 4.0 Internationab sicense.ifica . com at 04/26/2023 08:03:11AM 
56 Cinti S, Mitchell G, Barbatelli G, Murano I, Ceresi E, Faloia E, Wang S, Fortier M, Greenberg AS \& Obin MS. Adipocyte death defines macrophage localization and function in adipose tissue of obese mice and humans. Journal of Lipid Research 200546 2347-2355. (https://doi.org/10.1194/jlr.M500294-JLR200)

57 Lumeng CN, DeYoung SM, Bodzin JL \& Saltiel AR. Increased inflammatory properties of adipose tissue macrophages recruited during diet-induced obesity. Diabetes 200756 16-23. (https://doi. org/10.2337/db06-1076)

58 Nguyen MTA, Favelyukis S, Nguyen AK, Reichart D, Scott PA, Jenn A, Liu-Bryan R, Glass CK, Neels JG \& Olefsky JM. A subpopulation of macrophages infiltrates hypertrophic adipose tissue and is activated by free fatty acids via toll-like receptors 2 and 4 and JNK-dependent pathways. Journal of Biological Chemistry 2007282 35279-35292. (https://doi.org/10.1074/jbc.M706762200)

59 Oh DY, Morinaga H, Talukdar S, Bae EJ \& Olefsky JM. Increased macrophage migration into adipose tissue in obese mice. Diabetes 201261 346-354. (https://doi.org/10.2337/db11-0860)

60 Amano SU, Cohen JL, Vangala P, Tencerova M, Nicoloro SM, Yawe JC, Shen Y, Czech MP \& Aouadi M. Local proliferation of macrophages contributes to obesity-associated adipose tissue inflammation. Cell Metabolism 201419 162-171. (https://doi. org/10.1016/j.cmet.2013.11.017)

61 Braune J, Weyer U, Hobusch C, Mauer J, Brüning JC, Bechmann I \& Gericke M. IL-6 regulates M2 polarization and local proliferation of adipose tissue macrophages in obesity. Journal of Immunology 2017 198 2927-2934. (https://doi.org/10.4049/jimmunol.1600476)

62 Ramkhelawon B, Hennessy EJ, Ménager M, Ray TD, Sheedy FJ, Hutchison S, Wanschel A, Oldebeken S, Geoffrion M, Spiro W, et al. Netrin-1 promotes adipose tissue macrophage retention and insulin resistance in obesity. Nature Medicine 201420 377-384. (https://doi. org/10.1038/nm.3467)

63 Brestoff JR, Kim BS, Saenz SA, Stine RR, Monticelli LA, Sonnenberg GF, Thome JJ, Farber DL, Lutfy K, Seale P, et al. Group 2 innate lymphoid cells promote beiging of white adipose tissue and limit obesity. Nature 2015519 242-246. (https://doi.org/10.1038/ nature14115)

64 Liu PS, Lin YW, Burton FH \& Wei LN. Injecting engineered antiinflammatory macrophages therapeutically induces white adipose tissue browning and improves diet-induced insulin resistance. Adipocyte 20154 123-128. (https://doi.org/10.4161/21623945.2014.9 81438)

65 Kosteli A, Sugaru E, Haemmerle G, Martin JF, Lei J, Zechner R \& Ferrante AW. Weight loss and lipolysis promote a dynamic immune response in murine adipose tissue. Journal of Clinical Investigation $20101203466-3479$. (https://doi.org/10.1172/JCI42845)

66 Fitzgibbons TP \& Czech MP. Emerging evidence for beneficial macrophage functions in atherosclerosis and obesity-induced insulin resistance. Journal of Molecular Medicine 201694 267-275. (https:// doi.org/10.1007/s00109-016-1385-4)

67 Xu X, Grijalva A, van Skowronski A, van Eijk M, Serlie MJ \& Ferrante AW. Obesity activates a program of lysosomal-dependent lipid metabolism in adipose tissue macrophages independently of classic activation. Cell Metabolism 201318 816-830. (https://doi. org/10.1016/j.cmet.2013.11.001)

68 Satoh T, Kidoya H, Naito H, Yamamoto M, Takemura N, Nakagawa K, Yoshioka Y, Morii E, Takakura N, Takeuchi O, et al. Critical role of Trib1 in differentiation of tissue-resident M2-like macrophages. Nature 2013495 524-528. (https://doi.org/10.1038/nature11930)

69 Wu D, Molofsky AB, Liang HE, Ricardo-Gonzalez RR, Jouihan HA, Bando JK, Chawla A \& Locksley RM. Eosinophils sustain adipose alternatively activated macrophages associated with glucose homeostasis. Science 2011332 243-247. (https://doi.org/10.1126/ science.1201475)

70 Lee MW, Odegaard JI, Mukundan L, Qiu Y, Molofsky AB, Nussbaum JC, Yun K, Locksley RM \& Chawla A. Activated type 2 innate lymphoid cells regulate beige fat biogenesis. Cell $2015 \mathbf{1 6 0}$ 74-87. (https://doi.org/10.1016/j.cell.2014.12.011)

71 Lumeng CN, Bodzin JL \& Saltiel AR. Obesity induces a phenotypic switch in adipose tissue macrophage polarization. Journal of Clinical Investigation 2007117 175-184. (https://doi.org/10.1172/ JCI29881)

72 Boutagy NE, McMillan RP, Frisard MI \& Hulver MW. Metabolic endotoxemia with obesity: is it real and is it relevant? Biochimie 2016 124 11-20. (https://doi.org/10.1016/j.biochi.2015.06.020)

73 Murray PJ, Allen JE, Biswas SK, Fisher EA, Gilroy DW, Goerdt S, Gordon S, Hamilton JA, Ivashkiv LB, Lawrence T, et al. Macrophage activation and polarization: nomenclature and experimental guidelines. Immunity 201441 14-20. (https://doi.org/10.1016/j. immuni.2014.06.008)

74 Thomas AC \& Mattila JT. 'Of Mice and Men': arginine metabolism in macrophages. Frontiers in Immunology 20145 479. (https://doi. org/10.3389/fimmu.2014.00479)

75 Raes G, den Bergh RV, Baetselier PD \& Ghassabeh GH. Arginase-1 and Ym1 are markers for murine, but not human, alternatively activated myeloid cells. Journal of Immunology 2005174 6561-6562. (https:// doi.org/10.4049/jimmunol.174.11.6561)

76 Schneemann M \& Schoeden G. Macrophage biology and immunology: man is not a mouse. Journal of Leukocyte Biology 2007 81 579-579. (https://doi.org/10.1189/jlb.1106702)

77 Gross TJ, Kremens K, Powers LS, Brink B, Knutson T, Domann FE, Philibert RA, Milhem MM \& Monick MM. Epigenetic silencing of the human NOS2 gene: rethinking the role of nitric oxide in human macrophage inflammatory responses. Journal of Immunology 2014 192 2326-2338. (https://doi.org/10.4049/jimmunol.1301758)

78 Fjeldborg K, Pedersen SB, Møller HJ, Christiansen T, Bennetzen M \& Richelsen B. Human adipose tissue macrophages are enhanced but changed to an anti-inflammatory profile in obesity. Journal of Immunology Research 20142014 1-10. (https://doi. org/10.1155/2014/309548)

79 Li P, Lu M, Nguyen MTA, Bae EJ, Chapman J, Feng D, Hawkins M, Pessin JE, Sears DD, Nguyen AK, et al. Functional heterogeneity of CD11c-positive adipose tissue macrophages in diet-induced obese mice. Journal of Biological Chemistry 2010285 15333-15345. (https:// doi.org/10.1074/jbc.M110.100263)

80 Wentworth JM, Naselli G, Brown WA, Doyle L, Phipson B, Smyth GK, Wabitsch M, O’Brien PE \& Harrison LC. Pro-inflammatory CD11c+CD206+ adipose tissue macrophages are associated with insulin resistance in human obesity. Diabetes 201059 1648-1656. (https://doi.org/10.2337/db09-0287)

81 Nakajima S, Koh V, Kua LF, So J, Davide L, Lim KS, Petersen SH, Yong WP, Shabbir A \& Kono K. Accumulation of CD11c+CD163+ adipose tissue macrophages through upregulation of intracellular 11ß-HSD1 in human obesity. Journal of Immunology 2016197 3735-3745. (https://doi.org/10.4049/jimmunol.1600895: 27698011) 82 Zeyda M, Farmer D, Todoric J, Aszmann O, Speiser M, Györi G, Zlabinger GJ \& Stulnig TM. Human adipose tissue macrophages are of an anti-inflammatory phenotype but capable of excessive proinflammatory mediator production. International Journal of Obesity 200731 1420-1428. (https://doi.org/10.1038/sj.ijo.0803632)

83 Kratz M, Coats BR, Hisert KB, Hagman D, Mutskov V, Peris E, Schoenfelt KQ, Kuzma JN, Larson I, Billing PS, et al. Metabolic dysfunction drives a mechanistically distinct proinflammatory phenotype in adipose tissue macrophages. Cell Metabolism 201420 614-625. (https://doi.org/10.1016/j.cmet.2014.08.010)

84 Fassina G, Dorigo P, Badetti R \& Visco L. Effect of oxidative phosphorylation inhibitors on cyclic adenosine monophosphate synthesis in rat adipose tissue. Biochemical Pharmacology 197221 1633-1639. (https://doi.org/10.1016/0006-2952(72)90313-9)

85 Demine S, Tejerina S, Bihin B, Thiry M, Reddy N, Renard P, Raes M, Jadot M \& Arnould T. Mild mitochondrial uncoupling induces HSL/ ATGL-independent lipolysis relying on a form of autophagy in 3T3- 
L1 adipocytes. Journal of Cellular Physiology 2018233 1247-1265. (https://doi.org/10.1002/jcp.25994)

86 Maassen JA, Romijn JA \& Heine RJ. Fatty acid-induced mitochondrial uncoupling in adipocytes as a key protective factor against insulin resistance and beta cell dysfunction: a new concept in the pathogenesis of obesity-associated type 2 diabetes mellitus. Diabetologia 200750 2036-2041. (https://doi.org/10.1007/s00125007-0776-z)

87 Contreras L, Drago I, Zampese E \& Pozzan T. Mitochondria: the calcium connection. Biochimica et Biophysica Acta 20101797 607-618. (https://doi.org/10.1016/j.bbabio.2010.05.005)

88 Pershadsingh HA, Shade DL, Delfert DM \& McDonald JM. Chelation of intracellular calcium blocks insulin action in the adipocyte. PNAS 198784 1025-1029. (https://doi.org/10.1073/pnas.84.4.1025)

89 Wang Y, Ali Y, Lim CY, Hong W, Pang ZP \& Han W. Insulinstimulated leptin secretion requires calcium and PI3K/Akt activation. Biochemical Journal 2014458 491-498. (https://doi.org/10.1042/ BJ20131176)

90 Wang CH, Chen YF, Wu CY, Wu PC, Huang YL, Kao CH, Lin CH, Kao LS, Tsai TF \& Wei YH. Cisd2 modulates the differentiation and functioning of adipocytes by regulating intracellular Ca2+ homeostasis. Human Molecular Genetics 201423 4770-4785. (https:// doi.org/10.1093/hmg/ddu193)

91 Shi H, Halvorsen YD, Ellis PN, Wilkison WO \& Zemel MB. Role of intracellular calcium in human adipocyte differentiation. Physiological Genomics 20003 75-82. (https://doi.org/10.1152/ physiolgenomics.2000.3.2.75)

92 Wright LE, Vecellio Reane D, Milan G, Terrin A, Di Bello G, Belligoli A, Sanna M, Foletto M, Favaretto F, Raffaello A, et al. Increased mitochondrial calcium uniporter in adipocytes underlies mitochondrial alterations associated with insulin resistance. American Journal of Physiology: Endocrinology and Metabolism 2017313 E641-E650. (https://doi.org/10.1152/ajpendo.00143.2016)

93 Tormos KV, Anso E, Hamanaka RB, Eisenbart J, Joseph J, Kalyanaraman B \& Chandel NS. Mitochondrial complex III ROS regulate adipocyte differentiation. Cell Metabolism 201114 537-544. (https://doi.org/10.1016/j.cmet.2011.08.007)

94 Zhang Y, Marsboom G, Toth PT \& Rehman J. Mitochondrial respiration regulates adipogenic differentiation of human mesenchymal stem cells. PLOS ONE 20138 e77077. (https://doi. org/10.1371/journal.pone.0077077)

95 Keuper M, Jastroch M, Yi CX, Fischer-Posovszky P, Wabitsch M, Tschop MH \& Hofmann SM. Spare mitochondrial respiratory capacity permits human adipocytes to maintain ATP homeostasis under hypoglycemic conditions. FASEB Journal 201428 761-770. (https://doi.org/10.1096/fj.13-238725)

96 Wilson-Fritch L, Burkart A, Bell G, Mendelson K, Leszyk J, Nicoloro S, Czech M \& Corvera S. Mitochondrial biogenesis and remodeling during adipogenesis and in response to the insulin sensitizer rosiglitazone. Molecular and Cellular Biology 200323 1085-1094. (https://doi.org/10.1128/MCB.23.3.1085-1094.2003)

97 Böttcher H \& Fürst P. Microcalorimetric and biochemical investigations of thermogenesis and metabolic pathways in human white adipocytes. International Journal of Obesity and Related Metabolic Disorders 199620 874-881.

98 von Heimburg Dv, Hemmrich K, Zachariah S, Staiger H \& Pallua N. Oxygen consumption in undifferentiated versus differentiated adipogenic mesenchymal precursor cells. Respiratory Physiology and Neurobiology 2005146 107-116. (https://doi.org/10.1016/j. resp.2004.12.013)

99 Kraunsøe R, Boushel R, Hansen CN, Schjerling P, Qvortrup K, Støckel M, Mikines KJ \& Dela F. Mitochondrial respiration in subcutaneous and visceral adipose tissue from patients with morbid obesity. Journal of Physiology 2010588 2023-2032. (https://doi. org/10.1113/jphysiol.2009.184754)
100 Schöttl T, Kappler L, Braun K, Fromme T \& Klingenspor M. Limited mitochondrial capacity of visceral versus subcutaneous white adipocytes in male C57BL/6N mice. Endocrinology 2015156 923-933. (https://doi.org/10.1210/en.2014-1689)

101 Krief S, Lönnqvist F, Raimbault S, Baude B, Van Spronsen A, Arner P, Strosberg AD, Ricquier D \& Emorine LJ. Tissue distribution of beta 3-adrenergic receptor mRNA in man. Journal of Clinical Investigation 199391 344-349. (https://doi.org/10.1172/JCI116191)

102 Villaret A, Galitzky J, Decaunes P, Estève D, Marques MA, Sengenès C, Chiotasso P, Tchkonia T, Lafontan M, Kirkland JL, et al. Adipose tissue endothelial cells from obese human subjects: differences among depots in angiogenic, metabolic, and inflammatory gene expression and cellular senescence. Diabetes 201059 2755-2763. (https://doi.org/10.2337/db10-0398)

103 Vatier C, Kadiri S, Muscat A, Chapron C, Capeau J \& Antoine B. Visceral and subcutaneous adipose tissue from lean women respond differently to lipopolysaccharide-induced alteration of inflammation and glyceroneogenesis. Nutrition and Diabetes 20122 e51. (https:// doi.org/10.1038/nutd.2012.29)

104 Keuper M, Berti L, Raedle B, Sachs S, Böhm A, Fritsche L, Fritsche A, Häring HU, Hrabě de Angelis M, Jastroch M, et al. Preadipocytes of obese humans display gender-specific bioenergetic responses to glucose and insulin. Molecular Metabolism 201920 28-37. (https:// doi.org/10.1016/j.molmet.2018.11.006)

105 Campbell PJ, Carlson MG, Hill JO \& Nurihan N. Regulation of free fatty acid metabolism by insulin in humans: role of lipolysis and reesterification. American Journal of Physiology 1992263 E1063-E1069. (https://doi.org/10.1152/ajpendo.2006.263.6.E1063)

106 Reshef L, Olswang Y, Cassuto H, Blum B, Croniger CM, Kalhan SC, Tilghman SM \& Hanson RW. Glyceroneogenesis and the triglyceride/ fatty acid cycle. Journal of Biological Chemistry 2003278 30413-30416. (https://doi.org/10.1074/jbc.R300017200)

107 Flachs P, Rossmeisl M, Kuda O \& Kopecky J. Stimulation of mitochondrial oxidative capacity in white fat independent of UCP1: a key to lean phenotype. Biochimica et Biophysica Acta 20131831 986-1003. (https://doi.org/10.1016/j.bbalip.2013.02.003)

108 Guilherme A, Virbasius JV, Puri V \& Czech MP. Adipocyte dysfunctions linking obesity to insulin resistance and type 2 diabetes. Nature Reviews: Molecular Cell Biology 20089 367-377. (https://doi.org/10.1038/nrm2391)

109 Wilson-Fritch L, Nicoloro S, Chouinard M, Lazar MA, Chui PC, Leszyk J, Straubhaar J, Czech MP \& Corvera S. Mitochondrial remodeling in adipose tissue associated with obesity and treatment with rosiglitazone. Journal of Clinical Investigation $2004 \mathbf{1 1 4}$ 1281-1289. (https://doi.org/10.1172/JCI21752)

110 Yeo CR, Agrawal M, Hoon S, Shabbir A, Shrivastava MK, Huang S, Khoo CM, Chhay V, Yassin MS, Tai ES, et al. SGBS cells as a model of human adipocyte browning: a comprehensive comparative study with primary human white subcutaneous adipocytes. Scientific Reports 20177 4031. (https://doi.org/10.1038/s41598-017-04369-2)

111 Sörbris R, Nilsson-Ehle P, Monti M \& Wadsö I. Differences in heat production between adipocytes from obese and normal weight individuals. FEBS Letters 1979101 411-414. (https://doi. org/10.1016/0014-5793(79)81056-X)

112 DiGirolamo M, Newby FD \& Lovejoy J. Lactate production in adipose tissue: a regulated function with extra-adipose implications. FASEB Journal 19926 2405-2412. (https://doi.org/10.1096/ fasebj.6.7.1563593)

113 van der Merwe MT, Schlaphoff GP, Crowther NJ, Boyd IH, Gray IP, Joffe BI \& Lönnroth PN. Lactate and glycerol release from adipose tissue in lean, obese, and diabetic women from South Africa. Journal of Clinical Endocrinology and Metabolism 200186 3296-3303. (https:// doi.org/10.1210/jcem.86.7.7670)

114 Simoneau JA \& Kelley DE. Altered glycolytic and oxidative capacities of skeletal muscle contribute to insulin resistance in NIDDM. Journal https://ec.bioscientifica.com https://doi.org/10.1530/EC-19-0016 (c) 2019 The authors Published by Bioscientifica Ltd
This work is licensed under a Creative Commons Attribution-NonCommercial-NoDerivatives 4.0 Internationab License ifica com at $04 / 26 / 2023$ 08:03:11AM 
of Applied Physiology 199783 166-171. (https://doi.org/10.1152/ jappl.1997.83.1.166)

115 Ceperuelo-Mallafré V, Ejarque M, Serena C, Duran X, MontoriGrau M, Rodríguez MA, Yanes O, Núñez-Roa C, Roche K, Puthanveetil $\mathrm{P}$, et al. Adipose tissue glycogen accumulation is associated with obesity-linked inflammation in humans. Molecular Metabolism 20165 5-18. (https://doi.org/10.1016/j. molmet.2015.10.001)

116 Si Y, Palani S, Jayaraman A \& Lee K. Effects of forced uncoupling protein 1 expression in 3T3-L1 cells on mitochondrial function and lipid metabolism. Journal of Lipid Research 200748 826-836. (https:// doi.org/10.1194/jlr.M600343-JLR200)

117 Si Y, Shi H \& Lee K. Metabolic flux analysis of mitochondrial uncoupling in 3T3-L1 adipocytes. PLoS ONE 20094 e7000. (https:// doi.org/10.1371/journal.pone.0007000)

118 Mitrou P, Boutati E, Lambadiari V, Maratou E, Papakonstantinou A, Komesidou V, Sidossis L, Tountas N, Katsilambros N, Economopoulos T, et al. Rates of glucose uptake in adipose tissue and muscle in vivo after a mixed meal in women with morbid obesity. Journal of Clinical Endocrinology and Metabolism 200994 2958-2961. (https://doi.org/10.1210/jc.2008-2297)

119 Tejerina S, De Pauw A, Vankoningsloo S, Houbion A, Renard P, De Longueville F, Raes M \& Arnould T. Mild mitochondrial uncoupling induces 3T3-L1 adipocyte de-differentiation by a PPAR-independent mechanism, whereas TNF-induced de-differentiation is PPAR dependent. Journal of Cell Science 2009122 145-155. (https://doi. org/10.1242/jcs.027508)

120 Stefan N, Kantartzis K, Machann J, Schick F, Thamer C, Rittig K, Balletshofer B, Machicao F, Fritsche A \& Häring HU. Identification and characterization of metabolically benign obesity in humans. Archives of Internal Medicine 2008168 1609-1616. (https://doi. org/10.1001/archinte.168.15.1609)

121 Klöting N, Fasshauer M, Dietrich A, Kovacs P, Schön MR, Kern M, Stumvoll M \& Blüher M. Insulin-sensitive obesity. American Journal of Physiology: Endocrinology and Metabolism 2010299 E506-E515. (https://doi.org/10.1152/ajpendo.00586.2009)

122 Phillips CM \& Perry IJ. Does inflammation determine metabolic health status in obese and nonobese adults? Journal of Clinical Endocrinology and Metabolism 201398 E1610-E1619. (https://doi. org/10.1210/jc.2013-2038)

123 Wildman RP, Kaplan R, Manson JE, Rajkovic A, Connelly SA, Mackey RH, Tinker LF, Curb JD, Eaton CB \& Wassertheil-Smoller S. Body size phenotypes and inflammation in the women's health initiative observational study. Obesity 201119 1482-1491. (https:// doi.org/10.1038/oby.2010.332)

124 Karelis AD, Faraj M, Bastard JP, St-Pierre DH, Brochu M, Prud'homme D \& Rabasa-Lhoret R. The metabolically healthy but obese individual presents a favorable inflammation profile. Journal of Clinical Endocrinology and Metabolism 200590 4145-4150. (https:// doi.org/10.1210/jc.2005-0482)

125 Zhang HH, Halbleib M, Ahmad F, Manganiello VC \& Greenberg AS. Tumor necrosis factor-alpha stimulates lipolysis in differentiated human adipocytes through activation of extracellular signalrelated kinase and elevation of intracellular cAMP. Diabetes 200251 2929-2935 (https://doi.org/10.2337/diabetes.51.10.2929)

126 Gao D, Madi M, Ding C, Fok M, Steele T, Ford C, Hunter L \& Bing C. Interleukin- $1 \beta$ mediates macrophage-induced impairment of insulin signaling in human primary adipocytes. American Journal of Physiology: Endocrinology and Metabolism 2014307 E289-E304. (https://doi.org/10.1152/ajpendo.00430.2013)

127 van Hall G, Steensberg A, Sacchetti M, Fischer C, Keller C, Schjerling P, Hiscock N, Møller K, Saltin B, Febbraio MA, et al. Interleukin-6 stimulates lipolysis and fat oxidation in humans. Journal of Clinical Endocrinology and Metabolism 200388 3005-3010. (https://doi.org/10.1210/jc.2002-021687)
128 Hotamisligil GS, Murray DL, Choy LN \& Spiegelman BM. Tumor necrosis factor alpha inhibits signaling from the insulin receptor. PNAS 199491 4854-4858. (https://doi.org/10.1073/ pnas.91.11.4854)

129 Xie X, Sinha S, Yi Z, Langlais PR, Madan M, Bowen BP, Willis W \& Meyer C. Role of adipocyte mitochondria in inflammation, lipemia and insulin sensitivity in humans: effects of pioglitazone treatment. International Journal of Obesity 201742 213-220. (https://doi. org/10.1038/ijo.2017.192)

130 Ohashi K, Parker JL, Ouchi N, Higuchi A, Vita JA, Gokce N, Pedersen AA, Kalthoff C, Tullin S, Sams A, et al. Adiponectin promotes macrophage polarization toward an anti-inflammatory phenotype. Journal of Biological Chemistry 2010285 6153-6160. (https://doi.org/10.1074/jbc.M109.088708)

131 Maya-Monteiro CM, Almeida PE, D’Avila H, Martins AS, Rezende AP, Castro-Faria-Neto H \& Bozza PT. Leptin induces macrophage lipid body formation by a phosphatidylinositol 3-kinase- and mammalian target of rapamycin-dependent mechanism. Journal of Biological Chemistry 2008283 2203-2210. (https://doi.org/10.1074/jbc. M706706200)

132 Tang L, Okamoto S, Shiuchi T, Toda C, Takagi K, Sato T, Saito K, Yokota S \& Minokoshi Y. Sympathetic nerve activity maintains an anti-inflammatory state in adipose tissue in male mice by inhibiting TNF- $\alpha$ gene expression in macrophages. Endocrinology 2015156 3680-3694. (https://doi.org/10.1210/EN.2015-1096)

133 Lumeng CN, Deyoung SM \& Saltiel AR. Macrophages block insulin action in adipocytes by altering expression of signaling and glucose transport proteins. American Journal of Physiology: Endocrinology and Metabolism 2007292 E166-E174. (https://doi.org/10.1152/ ajpendo.00284.2006)

134 Keuper M, Dzyakanchuk A, Amrein KE, Wabitsch M \& FischerPosovszky P. THP-1 macrophages and SGBS adipocytes - a new human in vitro model system of inflamed adipose tissue. Frontiers in Endocrinology 20112 89. (https://doi.org/10.3389/fendo.2011.00089)

135 Stouthard JML, Oude Elferink RPJ \& Sauerwein HP. Interleukin-6 enhances glucose transport in 3T3-L1 adipocytes. Biochemical and Biophysical Research Communications 1996220 241-245. (https://doi. org/10.1006/bbrc.1996.0389)

136 Jager J, Grémeaux T, Cormont M, Le Marchand-Brustel Y \& Tanti JF. Interleukin-1beta-induced insulin resistance in adipocytes through down-regulation of insulin receptor substrate-1 expression. Endocrinology 2007148 241-251. (https://doi.org/10.1210/en.20060692)

137 Sartipy P \& Loskutoff DJ. Monocyte chemoattractant protein 1 in obesity and insulin resistance. PNAS 2003100 7265-7270. (https:// doi.org/10.1073/pnas.1133870100)

138 Nøhr MK, Bobba N, Richelsen B, Lund S \& Pedersen SB. Inflammation downregulates UCP1 expression in brown adipocytes potentially via SIRT1 and DBC1 interaction. International Journal of Molecular Sciences 201718 E1006. (https://doi.org/10.3390/ ijms18051006)

139 Goto T, Naknukool S, Yoshitake R, Hanafusa Y, Tokiwa S, Li Y, Sakamoto T, Nitta T, Kim M, Takahashi N, et al. Proinflammatory cytokine interleukin-1 $\beta$ suppresses cold-induced thermogenesis in adipocytes. Cytokine 201677 107-114. (https://doi.org/10.1016/j. cyto.2015.11.001)

140 Dahlman I, Forsgren M, Sjögren A, Nordström EA, Kaaman M, Näslund E, Attersand A \& Arner P. Downregulation of electron transport chain genes in visceral adipose tissue in type 2 diabetes independent of obesity and possibly involving tumor necrosis factor- $\alpha$. Diabetes 200655 1792-1799. (https://doi.org/10.2337/db051421)

141 Wolf Y, Boura-Halfon S, Cortese N, Haimon Z, Sar Shalom H, Kuperman Y, Kalchenko V, Brandis A, David E, Segal-Hayoun Y, et al. Brown-adipose-tissue macrophages control tissue innervation https://ec.bioscientifica.com https://doi.org/10.1530/EC-19-0016 (c) 2019 The authors Published by Bioscientifica Ltd
This work is licensed under a Creative Commons Attribution-NonCommercial-NoDerivatives 4.0 International License if $i c a$ com at $04 / 26 / 2023$ 08:03:11Am 
and homeostatic energy expenditure. Nature Immunology 201718 665-674. (https://doi.org/10.1038/ni.3746)

142 Camell CD, Sander J, Spadaro O, Lee A, Nguyen KY, Wing A, Goldberg EL, Youm YH, Brown CW, Elsworth J, et al. Inflammasomedriven catecholamine catabolism in macrophages blunts lipolysis during ageing. Nature 2017550 119-123. (https://doi.org/10.1038/ nature24022)

143 Balter NJ \& Schwartz SL. Accumulation of norepinephrine by macrophages and relationships to known uptake processes. Journal of Pharmacology and Experimental Therapeutics 1977201 636-643.

144 Fabbiano S, Suárez-Zamorano N, Rigo D, Veyrat-Durebex C, Stevanovic Dokic A, Colin DJ \& Trajkovski M. Caloric restriction leads to browning of white adipose tissue through type 2 immune signaling. Cell Metabolism 201624 434-446. (https://doi. org/10.1016/j.cmet.2016.07.023)

145 Kim KH, Kim YH, Son JE, Lee JH, Kim S, Choe MS, Moon JH, Zhong J, Fu K, Lenglin F, et al. Intermittent fasting promotes adipose thermogenesis and metabolic homeostasis via VEGF-mediated alternative activation of macrophage. Cell Research 201727 1309-1326. (https://doi.org/10.1038/cr.2017.126)

146 Bartelt A \& Heeren J. Adipose tissue browning and metabolic health. Nature Reviews: Endocrinology 201410 24-36. (https://doi. org/10.1038/nrendo.2013.204)

147 Abdullahi A, Chen P, Stanojcic M, Sadri AR, Coburn N \& Jeschke MG. IL-6 signal from the bone marrow is required for the browning of white adipose tissue post burn injury. Shock 201747 33-39. (https:// doi.org/10.1097/SHK.0000000000000749)

148 Han J, Meng Q, Shen L \& Wu G. Interleukin-6 induces fat loss in cancer cachexia by promoting white adipose tissue lipolysis and browning. Lipids in Health and Disease 201817 14. (https://doi. org/10.1186/s12944-018-0657-0)

149 Knudsen JG, Murholm M, Carey AL, Biensø RS, Basse AL, Allen TL, Hidalgo J, Kingwell BA, Febbraio MA, Hansen JB, et al. Role of IL-6 in exercise training- and cold-induced UCP1 expression in subcutaneous white adipose tissue. PLOS ONE 20149 e84910. (https://doi.org/10.1371/journal.pone.0084910)

150 Babaei R, Schuster M, Meln I, Lerch S, Ghandour RA, Pisani DF, Bayindir-Buchhalter I, Marx J, Wu S, Schoiswohl G, et al. Jak-TGF $\beta$ cross-talk links transient adipose tissue inflammation to beige adipogenesis. Science Signaling 201811 eaai7838. (https://doi. org/10.1126/scisignal.aai7838)

151 Lizcano F, Vargas D, Gómez Á \& Torrado A. Human ADMCderived adipocyte thermogenic capacity is regulated by IL-4 receptor. Stem Cells International 20172017 2767916. (https://doi. org/10.1155/2017/2767916)

152 Shiau MY, Lu HF, Chang YH, Chiu YC \& Shih YL. Characterization of proteins regulated by interleukin-4 in 3T3-L1 adipocytes. SpringerPlus 20154 242. (https://doi.org/10.1186/s40064-015-0980-0)

153 Cautivo KM \& Molofsky AB. Regulation of metabolic health and adipose tissue function by group 2 innate lymphoid cells. European Journal of Immunology 201646 1315-1325. (https://doi.org/10.1002/ eji.201545562)

154 Villarroya F, Cereijo R, Villarroya J, Gavaldà-Navarro A \& Giralt M. Toward an understanding of how immune cells control brown and beige adipobiology. Cell Metabolism 201827 954-961. (https://doi. org/10.1016/j.cmet.2018.04.006)

155 Miller LE, Jüsten HP, Schölmerich J \& Straub RH. The loss of sympathetic nerve fibers in the synovial tissue of patients with rheumatoid arthritis is accompanied by increased norepinephrine release from synovial macrophages. FASEB Journal $2000 \mathbf{1 4}$ 2097-2107. (https://doi.org/10.1096/fj.99-1082com)

156 Spengler RN, Chensue SW, Giacherio DA, Blenk N \& Kunkel SL. Endogenous norepinephrine regulates tumor necrosis factor- $\alpha$ production from macrophages in vitro. Journal of Immunology 1994 152 3024-3031.
157 Wankhade UD, Lee JH, Dagur PK, Yadav H, Shen M, Chen W, Kulkarni AB, McCoy JP, Finkel T, Cypess AM, et al. TGF- $\beta$ receptor 1 regulates progenitors that promote browning of white fat. Molecular Metabolism 201816 160-171. (https://doi.org/10.1016/j. molmet.2018.07.008)

158 Yadav H, Quijano C, Kamaraju AK, Gavrilova O, Malek R, Chen W, Zerfas P, Zhigang D, Wright EC, Stuelten C, et al. Protection from obesity and diabetes by blockade of TGF- $\beta /$ Smad3 signaling. Cell Metabolism 201114 67-79. (https://doi.org/10.1016/j. cmet.2011.04.013)

159 Petrus P, Mejhert N, Corrales P, Lecoutre S, Li Q, Maldonado E, Kulyté A, Lopez Y, Campbell M, Acosta JR, et al. Transforming growth factor- $\beta 3$ regulates adipocyte number in subcutaneous white adipose tissue. Cell Reports 201825 551.e5-560.e5. (https://doi.org/10.1016/j. celrep.2018.09.069)

160 Pallotta I, Sun B, Wrona EA \& Freytes DO. BMP protein-mediated crosstalk between inflammatory cells and human pluripotent stem cellderived cardiomyocytes. Journal of Tissue Engineering and Regenerative Medicine 201711 1466-1478. (https://doi.org/10.1002/term.2045)

161 Tseng YH, Kokkotou E, Schulz TJ, Huang TL, Winnay JN, Taniguchi CM, Tran TT, Suzuki R, Espinoza DO, Yamamoto Y, et al. New role of bone morphogenetic protein 7 in brown adipogenesis and energy expenditure. Nature $2008 \mathbf{4 5 4}$ 1000-1004. (https://doi. org/10.1038/nature07221)

162 Gustafson B, Hammarstedt A, Hedjazifar S, Hoffmann JM, Svensson PA, Grimsby J, Rondinone C \& Smith U. BMP4 and BMP antagonists regulate human white and beige adipogenesis. Diabetes 201564 1670-1681. (https://doi.org/10.2337/db14-1127)

163 Modica S, Straub LG, Balaz M, Sun W, Varga L, Stefanicka P, Profant M, Simon E, Neubauer H, Ukropcova B, et al. Bmp4 promotes a brown to white-like adipocyte shift. Cell Reports $2016 \mathbf{1 6}$ 2243-2258. (https://doi.org/10.1016/j.celrep.2016.07.048)

164 Whittle AJ, Carobbio S, Martins L, Slawik M, Hondares E, Vázquez MJ, Morgan D, Csikasz RI, Gallego R, Rodriguez-Cuenca S, et al. BMP8B increases brown adipose tissue thermogenesis through both central and peripheral actions. Cell 2012149 871-885. (https:// doi.org/10.1016/j.cell.2012.02.066)

165 Pellegrinelli V, Peirce VJ, Howard L, Virtue S, Türei D, Senzacqua M, Frontini A, Dalley JW, Horton AR, Bidault G, et al. Adipocyte-secreted BMP8b mediates adrenergic-induced remodeling of the neurovascular network in adipose tissue. Nature Communications 20189 4974. (https://doi.org/10.1038/s41467-018-07453-x)

166 Schulz TJ \& Tseng YH. Emerging role of bone morphogenetic proteins in adipogenesis and energy metabolism. Cytokine and Growth Factor Reviews 200920 523-531. (https://doi.org/10.1016/j. cytogfr.2009.10.019)

167 Varga T, Mounier R, Patsalos A, Gogolák P, Peloquin M, Horvath A, Pap A, Daniel B, Nagy G, Pintye E, et al. Macrophage PPARy, a lipid activated transcription factor controls a growth factor GDF3 and skeletal muscle regeneration. Immunity 201645 1038-1051. (https:// doi.org/10.1016/j.immuni.2016.10.016)

168 Hinoi E, Nakamura Y, Takada S, Fujita H, Iezaki T, Hashizume S, Takahashi S, Odaka Y, Watanabe T \& Yoneda Y. Growth differentiation factor-5 promotes brown adipogenesis in systemic energy expenditure. Diabetes 201463 162-175. (https://doi. org/10.2337/db13-0808)

169 Kim JM, Kosak JP, Kim JK, Kissling G, Germolec DR, Zeldin DC, Bradbury JA, Baek SJ \& Eling TE. NAG-1/GDF15 transgenic mouse has less white adipose tissue and a reduced inflammatory response. Mediators of Inflammation 20132013 1-10. (https://doi. org $/ 10.1155 / 2013 / 641851)$

170 Onishi Y, Fukasawa K, Ozaki K, Iezaki T, Yoneda Y \& Hinoi E. GDF1 is a novel mediator of macrophage infiltration in brown adipose tissue of obese mice. Biochemistry and Biophysics Reports 20165 216-223. (https://doi.org/10.1016/j.bbrep.2015.12.008) https://ec.bioscientifica.com https://doi.org/10.1530/EC-19-0016
(C) 2019 The authors Published by Bioscientifica Ltd
This work is licensed under a Creative Commons Attribution-NonCommercial-NoDerivatives 4.0 International License.ifica com at 04/26/2023 08:03:11Am 
171 Adela R \& Banerjee SK. GDF-15 as a target and biomarker for diabetes and cardiovascular diseases: a translational prospective. Journal of Diabetes Research 20152015 490842. (https://doi. org/10.1155/2015/490842)

172 Shen JJ, Huang L, Li L, Jorgez C, Matzuk MM \& Brown CW. Deficiency of growth differentiation factor 3 protects against dietinduced obesity by selectively acting on white adipose. Molecular Endocrinology 200923 113-123. (https://doi.org/10.1210/me.20070322)

173 Modica S \& Wolfrum C. The dual role of BMP4 in adipogenesis and metabolism. Adipocyte 20176 141-146. (https://doi.org/10.1080/216 23945.2017.1287637)

174 Emmerson PJ, Wang F, Du Y, Liu Q, Pickard RT, Gonciarz MD, Coskun T, Hamang MJ, Sindelar DK, Ballman KK, et al. The metabolic effects of GDF15 are mediated by the orphan receptor GFRAL. Nature Medicine 201723 1215-1219. (https://doi.org/10.1038/nm.4393)

175 Kelly B \& O’Neill LA. Metabolic reprogramming in macrophages and dendritic cells in innate immunity. Cell Research 201525 771-784. (https://doi.org/10.1038/cr.2015.68)

176 Sugimoto M, Sakagami H, Yokote Y, Onuma H, Kaneko M, Mori M, Sakaguchi Y, Soga T \& Tomita M. Non-targeted metabolite profiling in activated macrophage secretion. Metabolomics 20128 624-633. (https://doi.org/10.1007/s11306-011-0353-9)

177 Carrière A, Jeanson Y, Berger-Müller S, André M, Chenouard V, Arnaud E, Barreau C, Walther R, Galinier A, Wdziekonski B, et al. Browning of white adipose cells by intermediate metabolites: an adaptive mechanism to alleviate redox pressure. Diabetes 201463 3253-3265. (https://doi.org/10.2337/db13-1885)

178 Hanatani S, Motoshima H, Takaki Y, Kawasaki S, Igata M, Matsumura T, Kondo T, Senokuchi T, Ishii N, Kawashima J, et al. Acetate alters expression of genes involved in beige adipogenesis in 3T3-L1 cells and obese KK-Ay mice. Journal of Clinical Biochemistry and Nutrition 201659 207-214. (https://doi. org/10.3164/jcbn.16-23)

179 Sahuri-Arisoylu M, Brody LP, Parkinson JR, Parkes H, Navaratnam N, Miller AD, Thomas EL, Frost G \& Bell JD. Reprogramming of hepatic fat accumulation and 'browning' of adipose tissue by the short-chain fatty acid acetate. International Journal of Obesity $2016 \mathbf{4 0} 955-963$. (https://doi.org/10.1038/ijo.2016.23)

180 Dalli J \& Serhan CN. Specific lipid mediator signatures of human phagocytes: microparticles stimulate macrophage efferocytosis and pro-resolving mediators. Blood 2012120 e60-e72. (https://doi. org/10.1182/blood-2012-04-423525)

181 Masoodi M, Kuda O, Rossmeisl M, Flachs P \& Kopecky J. Lipid signaling in adipose tissue: connecting inflammation and metabolism. Biochimica et Biophysica Acta 20151851 503-518. (https://doi.org/10.1016/j.bbalip.2014.09.023)
182 Endo Y, Blinova K, Romantseva T, Golding H \& Zaitseva M. Differences in PGE2 production between primary human monocytes and differentiated macrophages: role of IL-1 $\beta$ and TRIF/IRF3. PLoS ONE 20149 e98517. (https://doi.org/10.1371/journal.pone.0098517)

183 García-Alonso V, Titos E, Alcaraz-Quiles J, Rius B, Lopategi A, LópezVicario C, Jakobsson PJ, Delgado S, Lozano J \& Clària J. Prostaglandin E2 exerts multiple regulatory actions on human obese adipose tissue remodeling, inflammation, adaptive thermogenesis and lipolysis. PLOS ONE 201611 e0153751. (https://doi.org/10.1371/journal. pone.0153751)

184 Suárez J, Rivera P, Arrabal S, Crespillo A, Serrano A, Baixeras E, Pavón FJ, Cifuentes M, Nogueiras R, Ballesteros J, et al. Oleoylethanolamide enhances $\beta$-adrenergic-mediated thermogenesis and white-to-brown adipocyte phenotype in epididymal white adipose tissue in rat. Disease Models and Mechanisms 20147 129-141. (https://doi.org/10.1242/dmm.013110)

185 Caër C, Rouault C, Roy TL, Poitou C, Aron-Wisnewsky J, Torcivia A, Bichet JC, Clément K, Guerre-Millo M \& André S. Immune cellderived cytokines contribute to obesity-related inflammation, fibrogenesis and metabolic deregulation in human adipose tissue. Scientific Reports 20177 3000. (https://doi.org/10.1038/s41598-01702660-w)

186 Wang B, Fu X, Liang X, Deavila JM, Wang Z, Zhao L, Tian Q, Zhao J, Gomez NA, Trombetta SC, et al. Retinoic acid induces white adipose tissue browning by increasing adipose vascularity and inducing beige adipogenesis of PDGFR $\alpha^{+}$adipose progenitors. Cell Discovery 20173 17036. (https://doi.org/10.1038/celldisc.2017.36)

187 Darwich L, Coma G, Peña R, Bellido R, Blanco EJJ, Este JA, Borras FE, Clotet B, Ruiz L, Rosell A, et al. Secretion of interferon- $\gamma$ by human macrophages demonstrated at the single-cell level after costimulation with interleukin (IL)-12 plus IL-18. Immunology 2009126 386-393. (https://doi.org/10.1111/j.1365-2567.2008.02905.x)

188 Moisan A, Lee YK, Zhang JD, Hudak CS, Meyer CA, Prummer M, Zoffmann S, Truong HH, Ebeling M, Kiialainen A, et al. White-tobrown metabolic conversion of human adipocytes by JAK inhibition. Nature Cell Biology 201517 57-67. (https://doi.org/10.1038/ncb3075)

189 Cypess AM, Lehman S, Williams G, Tal I, Rodman D, Goldfine AB, Kuo FC, Palmer EL, Tseng YH, Doria A, et al. Identification and importance of brown adipose tissue in adult humans. New England Journal of Medicine 2009360 1509-1517. (https://doi.org/10.1056/ NEJMoa0810780)

190 Porter C, Chondronikola M \& Sidossis LS. The therapeutic potential of brown adipocytes in humans. Frontiers in Endocrinology 20156 156. (https://doi.org/10.3389/fendo.2015.00156)

191 Nedergaard J \& Cannon B. The browning of white adipose tissue: some burning issues. Cell Metabolism 201420 396-407. (https://doi. org/10.1016/j.cmet.2014.07.005)

Received in final form 2 May 2019

Accepted 14 May 2019

Accepted Preprint published online 14 May 2019 https://ec.bioscientifica.com https://doi.org/10.1530/EC-19-0016
(C) 2019 The authors Published by Bioscientifica Ltd
This work is licensed under a Creative Commons Attribution-NonCommercial-NoDerivatives 4.0 Internationab License.ifica com at 04/26/2023 08:03:11AM 